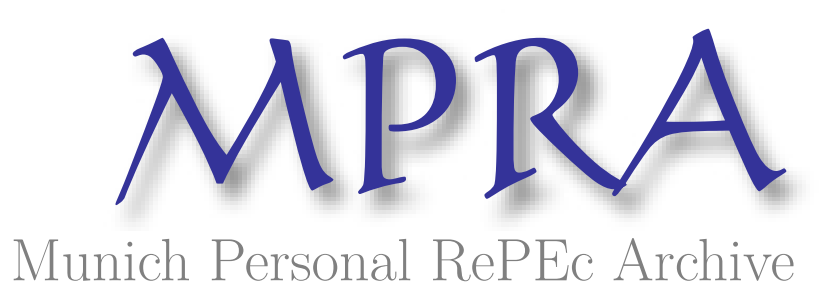

\title{
Customary versus Civil Law within Old Regime France
}

Le Bris, David

2013

Online at https://mpra.ub.uni-muenchen.de/52123/

MPRA Paper No. 52123, posted 11 Dec 2013 14:07 UTC 


\title{
Customary versus Civil Law within Old Regime France
}

\author{
David Le Bris \\ KEDGE Business School ${ }^{1}$
}

First version June 2013

This version November 2013

Comments welcome

\begin{abstract}
:
Law and finance theory emphasizes the negative consequences of civil law on financial and, subsequently, economic development. Before the Revolution, French territory was strictly divided according to the legal regime. Since the Middle-Ages, the southern part of France was under Justinian civil law and the north was under customary laws which, as with common law, gave more flexibility to judges and less right to the state. This dichotomy offers the unique opportunity to test the law and finance theory free from cross-country bias. Using fiscal revenues across 79 Departments from 1817-1821, we test if Departments under civil law, over the centuries and up to 15 years ago, exhibit lower financial and economic outcomes. We find that civil law Departments do exhibit lower economic performances but this difference is not robust when controlled for fundamental factors. The civil law appears even to have a positive effect in many specifications. Old Regime France does not confirm the law and finance theory.
\end{abstract}

Key words: Law and Finance, Economic development, France.

JEL codes: O43, O1, P48, N43.

\section{Introduction}

What are the causes of the large differences observed in the living standards across human communities? Law and finance theory (also called legal origin theory) proposes an attractive answer to this fundamental question by focusing on the legal origin (La Porta et al., 1997, 1998, 2000, hereafter LLSV). The first part of this theory is that financial development achieved in one country depends on the enforcement of private property rights, support of private contractual arrangements,

\footnotetext{
${ }^{1}$ david.lebris@gmail.com
} 
and protections of the legal right of investors. Second, the legal origin theory assumes that the legal tradition has a long-term impact on the attainment of these institutional qualities. Thus, the legal origin theory assumes that legal tradition provides an explanation for current financial development. The main claim of this theory is the superiority of common law compared to civil law in fostering financial development. Furthermore, financial development is proved to promote economic growth (see a survey in Pasali, 2013). This promotion of economic growth by financial development brings an additional causal relationship: the legal tradition helps to explain current economic development. This appealing theory remains highly discussed. Xu (2011) reports 15 articles of LLSV and 17 articles applying the methodology of LLSV supporting their conclusions and 17 articles and one book doubting their theory.

The present paper uses an original empirical field to test this theory. Law and finance studies present France as the model and source of the most frequent civil law regimes. This claim is true after the Revolution but arguably false during the Old Regime, at which time France was strictly divided in two parts. The south part was called, the "written law countries" (pays de droit écrit), and was under Roman law, namely the code of Justinian (Corpus iuris civilis). The northern part of France was under several customary laws (pays de droit coutumier) which are close to English common law. This dichotomy within Old Regime France provides similar opposition to the one tested by the law and finance literature between common and civil law countries in contemporaneous time.

Law and finance theory emphasizes two channels through which legal origin influences financial development and then economic outcomes (see Beck et al., 2003). First, the "political" channel contends that (a) legal traditions differ in terms of the priority that they attach to private property rights versus the rights of the State and (b) the protection of private contracting rights forms the basis of financial development (LLSV, 1999). English common law evolved to protect private property owners against the crown, whereas civil law provides a tool for state-control (La Porta et al., 2008). Second, the "adaptability" channel which stresses that (a) legal traditions differ in their ability to evolve with changing economic conditions (Hayek, 1960) and (b) legal traditions that adapt quickly to minimize the gap between the contracting needs of the economy and the legal system's capabilities will more effectively foster financial development than more rigid legal traditions. The judge-made law principle of common law is more efficient in adapting the law to new economic needs than the codes of the civil law regimes.

These theoretical mechanisms hold for Old Regime France. A "political" channel existed allowing the state to intervene more readily in the southern part of the country. Indeed, the French state could use the role conferred to the Roman Emperor by the Justinian code to gain rights whereas this way did not exist in the customary part of the country. The French king used the Caesarism of the Justinian text, placing the emperor above the law saying "the king is emperor in his kingdom" to fight against feudalism (Chénon, 1929, vol. 0, p. 507). The "adaptability" channel is also verified since in the civil law part of the country, the judge must refer to the corpus iuris civilis whereas he beneficiates from greater freedom in the customary area. In this part of France, it is forbidden for a judge to refer to the Roman codes in order to make decisions. As for modern common law, we can suspect the customary legal regime of northern France to have offered superior adaptability to social and economic needs. As in common law, the main source of law is the cases judged in customary France whereas in the civil law area, the law had been written in Constantinople during the $6^{\text {th }}$ century. 
The need for legal solutions in the Old Regime economy was just as crucial as those of more recent periods. Firstly, the $17^{\text {th }}$ and $18^{\text {th }}$ centuries spanned a period of great economic changes, including changes in farming methods. New farming methods required the clarification of property rights concerning the usage rights of the village communities (North and Thomas, 1973). In addition, the period saw the birth of large firms (manufactures), Atlantic trade (Acemoglu et al., 2005) and new financial tools (Hoffman et al., 2001). Secondly, the credit market of Old Regime France was welldeveloped and multiform. Today, the quality of legal rules influences savers to be more or less willing to invest. This is also the case during Old Regime France even if some of the then current legal rules known to play a role, for instance the protection of share-holders, do not make sense. Legal differences within Old Regime France lead to various practices on the credit market with clearly observable north/south differences (Hoffman et al., 2004). Thirdly, before the Revolution, the legal system was the result of about eight centuries of accumulated rules and contracts originally based on feudality, whereas the social system had evolved, making necessary legal adaptations along the way.

We test the prediction of higher financial and thus economic development in the customary area compared to civil law part of France. According to legal origin theory, the civil law area, compared to the customary area, suffered centuries of legal institutions that upset financial development. The centuries of comparatively higher financial development in the customary area should have allowed a higher level of economic growth and thus better economic performance. We use data of the period following the end of the Napoleonic era (1817-1821). If the legal context is crucial enough to affect strongly the economic outcomes, it should still be observable 13 years after the introduction of a common legal system: the Code Civil in 1804.

With the Revolution, France was divided in 86 Departments (Départements) from which 48 were previously under customary law, 31 under civil law and 7 partially under the two legal systems. To measure economic outcomes, we use fiscal and census data: TAX paid per capita and the number of DOORS AND WINDOWS per capita. To assess financial development, we measure the amount of CONTRACTS per capita using a tax paid on all notarized transactions (droits d'enregistrement) mainly real estate transactions and loans. For simplicity, we use the term "economic development" to refer to each of these three measures. We use the census of 1822 to gain a measure of inhabitants per Department, to convert these three measures into per capita figures. In 1817, two years after the end of the Napoleonic Empire, the economic and administrative situation was stable enough to allow significant measures. We use an average over 1817-1821 to smooth exceptional local variations due to, for example, a bad crop yield. We use a variety of variables to control for fundamental factors explaining differences in economic development across France.

The main contribution of this paper is to analyze and test law and finance theory on a single country sample rather than the typical international comparisons, bringing new data to bear on a hot issue. Our empirical field offers three categories of advantages. First, compared to international tests of legal origin theory, this within France analysis allows us to escape several potential other factors. International comparisons are notoriously plagued by the difficulty of netting out the effects of other fundamental causes of economic development (Acemoglu et al., 2005). Recent research highlights several explanations for economic development, from which this paper is forearmed, such as the English and Protestant culture (Stulz and Williamson, 2003), conditions of transplantation of the legal regime (Acemoglu et al., 2001), effects of very long-term history, such as the state of technologies 
centuries ago (Comin et al., 2010), the birth of a state (Bockstette et al., 2002) ${ }^{2}$, year 1500, the origin of current population (Putterman and Weil, 2010), the level of genetic diversity (Ashraf and Galor, 2013) and share of European population (Easterly and Levine, 2012).

Second, our period of analysis avoids the heterogeneous structural effects of the industrial Revolution. Our observations are free from the effect of the presence of coal and iron mines, which will provide large advantages to several locations in the following decades (Pomeranz, 2000). It is also before the railways, which could at the same time be a consequence of previous economic development (the railways are designed to serve the richest part of the population) and bring large advantages to the future development of areas served. Third, our measures of economic outcomes can be compared without any serious doubt since they come from a homogeneous fiscal system and reliable census data.

Customary law Departments exhibit a significantly higher economic development but fundamental factors also need to be controlled for. Several exogenous factors are identified to explain the economic development of a Department. The number of kilometers of navigable rivers and the historical presence of a Parliament in a Department are favorable to economic development, whereas a high average altitude, the quantity of rain, the distance from Paris, and the distance from the closest university lead to weaker economic development. After control for one or several of these fundamental factors, the higher economic development of the customary part of the country disappears. Worst, the first prediction of the legal origin theory, i.e. a higher financial development, is not verified since civil law Departments show a higher amount of CONTRACTS per capita after control for either fundamental factors or the general level of development.

This study is organized as follows. The next section details the historical background of the two French legal regimes. Section 2 explains the data we use. Section 3 measures the higher economic development of the customary area. Section 4 rejects the legal explanation after control for fundamental factors in Section 4. Section 5 focuses on the financial development in the civil law area. Section 6 provides several tests of robustness for the rejection. The last section concludes.

\section{Historical background}

\section{Old Regime France, legal dichotomy and diversity}

Despite the gradual expansion of the kingdom of France, existing local laws remained in force up to 1789. Voltaire mocked France's fragmented pre-Revolution legal system by writing, "When you travel in this Kingdom, you change legal systems as often as you change horses." (in Beck, Demirgüç-Kunt and Levine, 2003). ${ }^{3}$ Indeed, about 80 general customs and 380 local customs were in force within the Old Regime France. These various legal regimes were applied by several forms of court and not only a royal justice; the decline of feudal and municipal justice was only gradual (Chénon, 1929, vol. I, p.

\footnotetext{
${ }^{2}$ Even if all the Departments had not been attached to the French state during the same dates, all parts of France beneficiated from one state for about the same period.

${ }^{3}$ Also, Voltaire : " a lawyer who is very learned in his city, will be an ignoramus in the nearby town, Dialogue entre un plaideur et un avocat.
} 
491). ${ }^{4}$ There was sometimes up to four levels of courts of appeal (Chénon, 1929 vol. 0, p. 886). Even for last resort cases, 14 Parliaments existed across France to act as "supreme court". ${ }^{5}$ As an example, the Parliament of Paris judged in last resort cases according to 50 different customs (Chénon, 1929, vol. I, p. 323). Montesquieu was highly favorable to this diversity as a guarantee against potential despotism of one unique law. ${ }^{6}$ According to Montesquieu, the laws are "the necessary relations derived from the nature of things" (Esprit des Lois, I, 1) they are forged by history and determined by the environment in which they appear. They must be diversified, as diversified are the peoples.

This diversity of the legal regimes was headed by a strict partition between two legal principles. Northern France was under customary law (pays de coutumes, customary country) whereas the southern part (pays de droit écrit, written law country) was under Roman law, namely the corpus juris civilis of Justinian (Ourliac and Malafosse, 1968, vol. 3, p. 7). ${ }^{7}$ In the South, Roman law was positive law and the "written law" had to be taken into account in all circumstances (lex scripta) (Bellomo, 1995 p. 102). Since the Roman civil law was in force in written law country, the judge had to apply the comprehensive Justinian code, which offered him less freedom and initiatives than in customary country (Declareuil, 1925, p. 825). The strict application of the Justinian law in written law country is reinforced in the $16^{\text {th }}$ century, because the Roman law "reborn a second time" with new methods and new texts, better distributed through print (Chénon, 1929, vol. I, p. 329).

In customary country, the Roman law could only have a doctrinal influence as in English common law (Plucknett, 1939). ${ }^{8}$ In the northern part of France, Roman law was not the "law" that had the force of positive law but was valid only if a judge wanted to take it into account as ratio scripta for its power of suggestion and as a "reasonable" aid in making a difficult judicial decision. But lawyers in trial could not refer to the Justinian codes in the customary area according an Ordinance of Philippe III in 1278. ${ }^{9}$ In Paris, the teaching of the Roman law was forbidden from 1219 (Decretal Super Speculam of Honorius III). ${ }^{10}$ In 1219, the French king Philippe-Auguste, asked the Pope to ban the teaching and learning of Roman law in Paris. The penalties for both students and teacher were excommunication and a ban on practicing law. The French king did not want that, in his capital, people studied texts saying that they must obey a Roman Emperor since his Germanic enemy pretend to be the Holy Roman Emperor. The justification is: "In lle de France and others Provinces, we do not use the law of the Roman Empire."11 Others argue this ban is a will of the Pope to promote the study of the Canon

\footnotetext{
${ }^{4}$ This diversity contrast with the English case of centralized law following reforms instituted during the reign of Henry II (1154-1189). The new system became known as the "common law" because it was a law for the entire kingdom, in contrast to the varied customs applied by local courts (Klerman and Mahoney, 2007). The English law was thus highly centralized compared to the French one.

${ }^{5}$ List of Parliaments : Paris, Besançon, Toulouse, Bordeaux, Grenoble, Dijon, de Normandie, Aix, de Dombes, de Bretagne, Pau, Metz, de Flandres and Nancy.

${ }^{6}$ "Le monarque, qui connaît chacune de ses provinces, peut établir diverses lois ou souffrir différentes coutumes, mais le despote [...] gouverne par une volonté rigide qui est partout la même; tout s'aplanit sous ses pieds " $(E L, V I, 1)$.

${ }^{7}$ For an English reference, see Watson (1987), p. 555-556.

8 "Event at the present days, English courts upon occasion will refer to Roman law in something like Bracton's spirit in rare case where the native law give no guidance." (Plucknett, 1956, p. 300). See also, Oliver (1936).

${ }^{9} 7$ january 1278, article 9: "Li advocats ne soient si hardis d'ens mesler d'alléguer le droit escrit là où les coustumes aient lieu, mais usent de coustumes.» (Rigaudière, 1996).

${ }^{10}$ However, the Roman law remains taught in the University of Orleans.

${ }^{11}$ Chénon, 1929, vol. 0, p. 507.
} 
law. ${ }^{12}$ The study of the Roman law was allowed again in Paris in 1679 (Edit de Saint Germain en Laye of Louis XIV) but a strong primacy was given to courses and teachers of the "French customary law".

\section{Origin of the legal dichotomy}

Official boundaries of the Roman law part of France are finally fixed during the $13^{\text {th }}$ and $14^{\text {th }}$ centuries. In 1164, the representatives of the Viscountess of Narbonne to Louis VII claim their territories fell under Roman law from immemorial time (Rigaudière, 1996). The term 'written law country' (jus scriptum) appears in 1250 in an Ordinance of Blanche de Castille (Chénon 1929, vol. 0, p. 488). This Ordinance confirms one specific land is under Roman law for immemorial times but can also be accepted as a general rule for the southern part of the country (Rigaudière, 1996). The king of France recognizes the existence $a b$ antiquo of Roman law and defines the areas as early as 1270 . This recognition of the application of the Roman law in southern France is favorable to the French King. The French king used the legal role conferred to the Emperor by the Justinian code to assert his authority and power on the annexed southern provinces. Acting as an Emperor in his kingdom, the French King used the Roman law to increase the rights of the crown.

The origin of the legal dichotomy can be explained by history. The Roman law area is where Roman domination was the oldest and deepest. Then, this population has been the least mixed with German invaders and retained its own specific law even under the domination of the Germans (Klimrath, 1837). The written law country is approximately the same as the territory previously occupied by Visigoths and Burgundians, which issued for their Gallo-Roman subjects the Lex Romana Burgundionum and, the influential Breviarium Alaricianum. ${ }^{13}$ Others also point out the role of the notaries to diffuse the rediscovered Roman law from Italy since 1160 (Gouron, 1957). In any case, this legal partition between customary and civil law is exogenous to the economic development that reached across modern France.

\section{Writing of customs}

Before the $15^{\text {th }}$ century, customs were sometimes written but without any official approval. In cases of a lawsuit, the judge stated if the applicable custom was known of him (notoire) or not. If the custom was not notoire, the judge required a "turbe" which was a group of at least 10 people who could confirm unanimously the existence of a custom (Pissard, 1910). This system is similar to what was called the jury in England (Klerman and Mahoney, 2007). The system of turbe disappeared in 1667 after all the customs having been written. Customs have been gradually written after the Ordinance of Montil-Lès-Tours in 1454. The written customs were not a codification (Ourliac and Malafosse, 1968, p.8), the nature of the custom remains: "It is the people who made the law » (Coquille, 1665). Written customs are short documents: 190 articles for the custom of Paris written in 1510 , then double that number when the custom of Paris was modified in 1580. These customs were collected in books called Coutumier Général as early as 1536 (Chénon, 1929, vol. I, p. 363). The Coutumier Général from Bourdot de Richebourg published in 1724 is the most comprehensive $(1,200$

\footnotetext{
${ }^{12}$ About these debates, see Gioordanengo (1992).

${ }^{13}$ Except the Poitou, Berry and Haute-Bourgogne which are under customary law.
} 
pages). Common law countries also have codes, such as the Uniform Commercial Code in the United States, and the many codes of the State of California (see, Weiss, 2000 Herman, 1996 and Donald, 1973). Some of these codes have even more statutes than the equivalent civil law codes. Merryman (1969) explains that the codes in common law countries often summarize prior judicial decisions, which is exactly the process of the written customs of the Old Regime France.

Customs also existed in written law country but mainly for cities and several Pyrenean valleys whereas the customs were for whole areas in customary law country. But more importantly, these customs only deal with specific issues. When a novelty appeared in written country, the judge would have no choice but to respect Justinian law, whereas the judge in customary country was free make a bespoke ruling. These urban customs were written early to affirm what was different in the local practice compared to the standard Justinian law, which was at that time rediscovered as a whole. For example, the custom of the city of Toulouse, published in 1286, officially stated that the previous jurisprudence of the municipal justice was to be applied in most cases to defend the local practices while the standard Roman law was applied by the royal justice in the whole County of Toulouse after its annexation in 1271.

\section{Judge-made law}

In a few cases, the King created the law through ordinances, but this was mainly for public and procedural issues (Chénon 1929, vol. 0, p. 530). A Parliament could refuse or correct the ordinance of the King (it was called a Remontrance) even if the king had the last word, but this long and complicated procedure was used infrequently (Chénon, 1929, vol. I, p. 347); La Fronde (1648-1653) civil war was in fact due to such a conflict between the King and the Parliaments. The most important ordinance for business was the Ordonance de Commerce (called Code Savary) promulgated by JeanBaptiste Colbert in 1673, which was a written account of the practices that were at that time followed by merchants. After 1730 , several ordinances dealt with private law to try to unify rules across the kingdom. The result of this movement was the enhancement of the duality of the legal system, with a partial unification of the customary country via the custom of Paris and a strict respect of Justinian code in written law country (Chénon, 1929, vol I, p. 317).

French judges were independent from the power. Ironically, venality made French judges more independent than their English counterparts, for example. Most French judges were not selected by the king, and he could not remove them except in extraordinary circumstances (Klerman and Mahoney, 2007). All offices were allowed to be officially sold in France from $1522^{14}$ and inherited then from 1604 in exchange of an annual tax of 1/60 of the value of the inherited office (Chénon, 1929 , vol. I, p. 565). ${ }^{15}$ From a legal point of view, what were sold were the revenues of the office and not the office itself. This system is still the same today for the office notary; a notary should have a degree and the property of an office. A new officer (or after a change of king) needed to obtain a "lettre de confirmation" from the King, which was only a tax because they had to pay for it, (Bodin,

\footnotetext{
${ }^{14}$ Before 1522, thanks to a Canonic law, it was admitted that an officer presents his successor leading to occult financial transactions.

${ }^{15}$ After 1648 an additional tax of $1 / 6$ is paid each 9 years.
} 
1576 in Chénon, 1929, vol. I, p. 341) and at a later stage they would have to pass an examination. ${ }^{16}$ The property of one office is quickly considered as real estate and thus can be sold, exchanged, pawned, seized... This private property nature of the office gave the judges a near-perfect level independence from the state, which exerted direct control over neither their promotion nor their resignation.

This independence helped Parliamentarians to affirm themselves. The Parliaments applied the rule of precedent (case law). Since they were the jurisdictions of last resort, one Parliament could judge a new case as an Arrêt de Règlement, meaning it will then always be judged in the same way. One Arrêt de Règlement is thus imposed onto inferior jurisdictions (Chénon, 1929, vol. 0, p. 530 and vol. I, p. 362). The first Arrêt de Règlement was from the Parliament of Paris in 1353. Due to the fact there were 14 different Parliaments, one Arrêt de Règlement could then be imitated in another Parliament or not. This procedure is similar to "precedent case" in the common law. ${ }^{17}$

The wide freedom of judges to decide cases led to a very rich jurisprudence (even in written law country). Collections of cases are recorded. A famous one is by Louet (1602), augmented by Brodeau (1614) and then Rousseau de La Combe (1742). Each Parliament generates specific publications of their jurisprudence. ${ }^{18}$ During the $18^{\text {th }}$ century, these collections were presented in the form of dictionaries (Malafosse and Ourliac, 1968, vol. III, p. 17). The most comprehensive is the Répertoire universel et raisonné de jurisprudence civile, criminelle, canonique et bénéficiale of Joseph-Nicolas Guyot, published between 1775 and 1783. It represents 65 volumes of about 550 pages each, meaning about 35,750 pages of jurisprudence.

\section{Legal issues of economic problems}

A large part of this jurisprudence stemmed from economic issues. Legal origin theory first emphasizes the impact of the legal regime on the rules governing financial activities. Financial activities were developed early. Studies suggest that financial factors may have been even more important in promoting growth in the $17^{\text {th }}, 18^{\text {th }}$ and $19^{\text {th }}$ centuries than they are today (Bordo and Rousseau, 2006). About 50,000 notary acts dealing with credit are observed in 1700 in Paris (Hoffman et al., 2001). A study of loans contracted in a town in southeastern France between 1630 and 1788 suggest that credit markets were both active and flexible (Rosenthal, 1993). A large and diversified credit market also existed in the rural, "less-developed" areas in the $17^{\text {th }}$ century (Ogilvie et al., 2012, Postel-Vinay, 1998).

The financial activities suffered sometimes due to the legal fragmentation, making crucial the role of jurisprudence. For instance, the perpetual annuity, a standard financial tool of the time, was considered as movable property in several customs (Blois, Reims, Troies, Lorraine...), as immovable property in others (Paris, Orléans...) and was unknown to the Justinian code. The owner of a

\footnotetext{
${ }^{16}$ Gradually, the king sold offices not only for justice but for all possible officials taxing something; according to Voltaire 40,000 offices were sold between 1691 and 1709 including controller stacking wood, controller fresh butter, salted butter tester....

${ }^{17}$ The explicit reliance on precedent as a source of law (and the term precedent itself) is only a $17^{\text {th }}$ and $18^{\text {th }}$ century development in England (Berman, 2003) in La Porta et al., 2008.

${ }^{18}$ Toulouse by La RocheFlavin (1617), Maynard (1618), Catelan (1703), d'Olive (1638) ; Bordeaux by Boyer and Boerius (1603), Rouen by Froland (1740), Rennes by Poullain du Parc (1737)...
} 
perpetual annuity living under a custom accepting it as an immovable property was able to mortgage it as any real-estate. If the owner of the annuity were to move his home to a city under a custom considering perpetual annuity as movable property, the beneficiary of the mortgage lost his right. In 1697, to solve this conflict, an arrêt of the Parliament of Paris said that the mortgage still existed despite this perpetual annuity not being an immovable property any more (Guyot, 1787, vol. 53, p. 445).

Before the industrial Revolution, the main economic issue was agriculture. The country as a whole was confronted by new farming methods, which required a more complete system of land property. In many cases, the owner of land shared its use with the community which owned usage rights, such as grazing rights (vaine pature meaning the entire ownership of a piece of land is limited to only a few months before the harvest, all the community are allowed to use it the rest of the time); personal use of wood for heating and building; the interdiction to change a pasture to a sown field; the gleaning right, which imposed a minimal size of the cut straw stems, leading to the ban of the scythe by several Parliaments; it was sometimes required to entrust the landowner's cattle to the common shepherd ... (Avenel, 1910). To be able to change the farming methods implies that property rights had previously been clarified. Another embedded property resulted from feudal rights. Most of lands were initially owned by a lord that had leased land in exchange for several rights (bail à cens). Depending on the contract, the owner of a land should have to pay a rent in nature (limiting the possibility to change the production) or to refer to his lord in many situations. These legal issues are also crucial when massive investments were to be undertaken to drain or irrigate unproductive lands (Rosenthal, 2009).

As an example, the cases from one feudal tax on transactions (called lods et vente) enforced by one lord is presented in an 800 page book (Molière-Fonmaur, 1783). This book deals with numerous different cases of tax on agreement to sell, forced sale, auction, sale of rights, sale of mortgage, sale by the clergy, sale of easements, sale of the right to act, sharing, exchange, sale with right of repurchase, repurchase, gifts, dowries, inheritance, cancellation of sale, emphyteutic lease, sale by the land-lord, various forms of ownership (fief, usufruct, bare ownership, free-hold, attached objects, boats, mills ...), payment date, how to calculate the value of property, the tax rate... So many issues for which the adaptability of the customary law is expected to provide better answers to new economic needs than the Roman law codified in the $6^{\text {th }}$ century in the Eastern Roman Empire.

\section{Data}

\section{Dummy variable for the legal regime}

To characterize the legal regime of each area, we use the work of Henri Klimrath (1837), Carte de la France coutumière, which provides a detailed limit of the customary and civil areas. Figure 1 shows the two legal systems and the frontiers of the judicatures of the 14 Parliaments. The civil law part of France was ruled by five sovereign courts: the Parliaments of Bordeaux, Toulouse, Pau, Aix, and Grenoble, the Conseils souverains of Roussilon and, for several specific locations, the Parliaments of Paris $^{19}$ and Dijon. The rest of France is under customary law. In 1790, 86 Departments, based on

\footnotetext{
${ }^{19}$ A specific element of the Parliament of Paris was dedicated to civil law whereas most of its judicature was under customary law.
} 
geography, are substituted to the previous administrative entities. Each of these Departments lodges a commissary of the state (Préfet) in, most cases, the main city, which is then called the Préfecture. 48 of these Departments were previously under customary law, 31 under civil law and 7 partially under the two legal systems. We use these new entities, the Departments, in the following analysis.

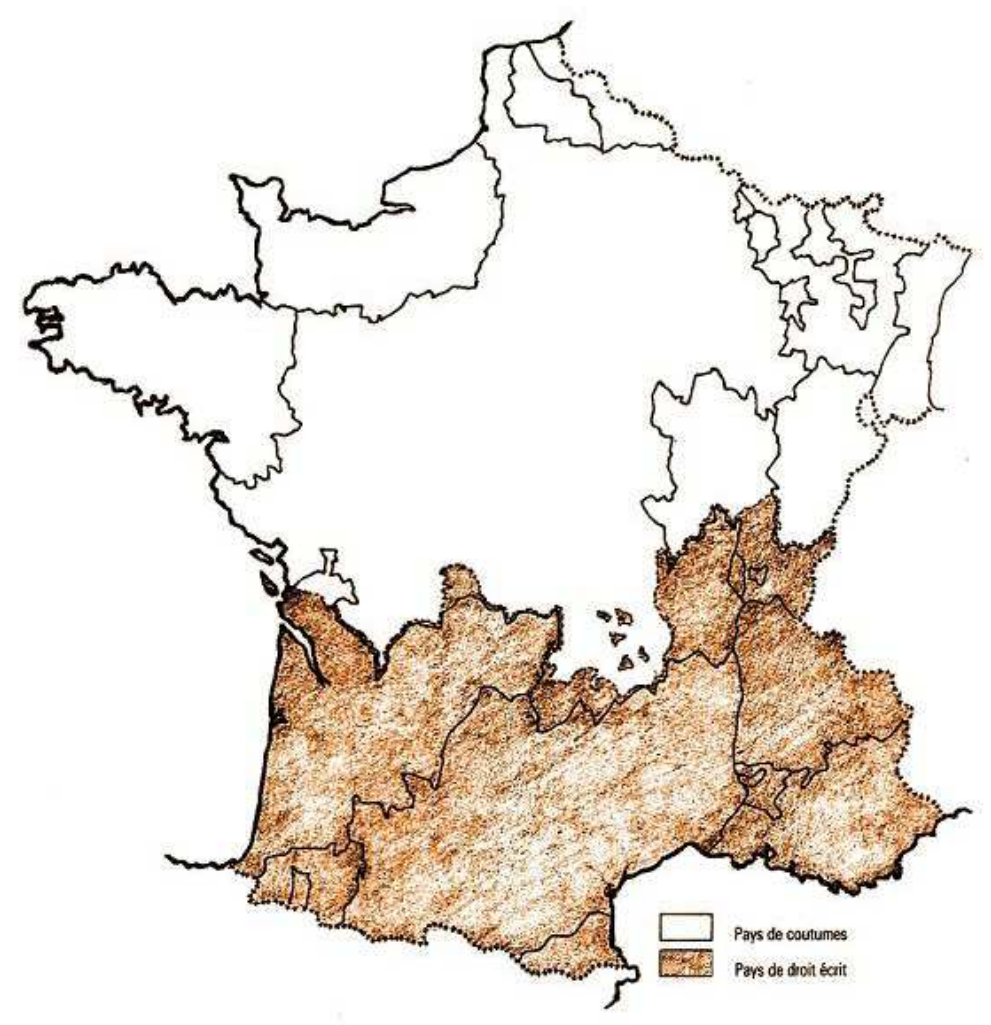

(d'après la carte de la France coutumière dressée en 1837 par Henri Klimrath)

Figure 1, Map of civil and customary parts of France before 1789

\section{Measures of economic development}

Our first economic measure is called TAX. We collect the amount of direct taxes paid in each Department. These direct taxes will then be known as the "four vieilles" (four olds) since these four taxes remained unchanged for decades. The first one (contribution foncière) is a tax on the value of real estate (land and building) paid by the owner. ${ }^{20}$ The second one (contribution personnelle mobilière) is a tax on the value of houses, but paid by the occupant and not the owner. ${ }^{21}$ The third one (patente) is a tax on business (trade and industry) mainly based on the value of the building occupied. ${ }^{22}$ The last one (portes et fenetres) is a tax on the number of doors and windows visible from the street, again paid by the occupant and not the owner. ${ }^{23}$

\footnotetext{
${ }^{20}$ loi des 23 novembre - 1er décembre 1790.

${ }^{21}$ loi des 13 janvier - 18 février 1791.

${ }^{22}$ loi du 2-17 mars 1791.

${ }^{23}$ loi du 4 Frimaire an VII : 24 mars 1798.
} 
These taxes provide a correct measure of the economic development of one Department, which is comparable across France since rates and methods of taxation are similar. These taxes are only weakly dependent on the business cycle and could sometimes be underestimated since they are mainly based on a difficult exercise of valuation of properties; a taxpayer can contest the case of overestimation of the values used to tax, thus underestimation is probably more frequent than overestimation. To avoid any effect of local variation of the economic conditions, we use an average of five years (1817-1821). Then, we use the population of each Department from the census of 1822 to obtain the TAX paid per capita in each Department. Figure 2 shows the important differences across the country we observe. An average of 11.79 francs is paid by French people with inhabitants in Seine paying on average 13.69 times more than those in Corse (Table1).

Our second measure, CONTRACTS, is also fiscal data, but provides an assessment of financial development. We collect the amount of tax paid as Enregistrement in each Department. The "Droit d'enregistrement" is a tax paid on the value of all notarized contracts. Enregistrement tax is an efficient way to measure financial development as it is a fixed rate (depending on the kind of transaction) applied on all contracts recorded by a notary including gift-making and inheritance, but the main base of taxes are sales, personal loans and mortgages. Before the development of the banking system, notaries provided a large allocation of capital. Mortgages through notaries represented 40\% of the GDP of France in 1840 (Hoffman et al., 2011). Again, we use an average of five years of tax (1817-1821), we then divided the figures by the population of each Department according to the census of 1822. Figure 3 highlights that together with the Parisian region, the Departments with the highest value of CONTRACTS per capita are those of the big commercial cities of Marseille, Lyon and Rouen. Extremes are again Seine and Corse with a magnitude of 16.91 times.

Our last measure is the number of DOORS AND WINDOWS per capita. We use the data of the census of 1822 , which provides the number of doors and windows and this number is divided by the number of inhabitants of each Department according to this same census. This measure reflects the standard of living in terms of real estate, since it constitutes a proxy for the number of houses and rooms per capita. To enjoy a high number of DOORS AND WINDOWS per capita implies to have previously financed these buildings. France exhibits large variations in local architectures but there is nothing preventing the building of more houses, rooms and windows. One of these variations is the adaptation of the buildings to the heat in the south. But this adaptation encompasses a smaller overall size of windows in the south without an impact on the number of windows. Thus, the number of DOORS AND WINDOWS per capita is a suitable measure of the economic development reached in one area. On average a French person has 1.1 DOORS AND WINDOWS. Due to higher population density, Departments with important cities, as the Seine with Paris, do not exhibit high economic development according to this measure. The dispersion is more limited with the inhabitants of Eure enjoying 3.25 more DOORS AND WINDOWS than those of Creuse. 


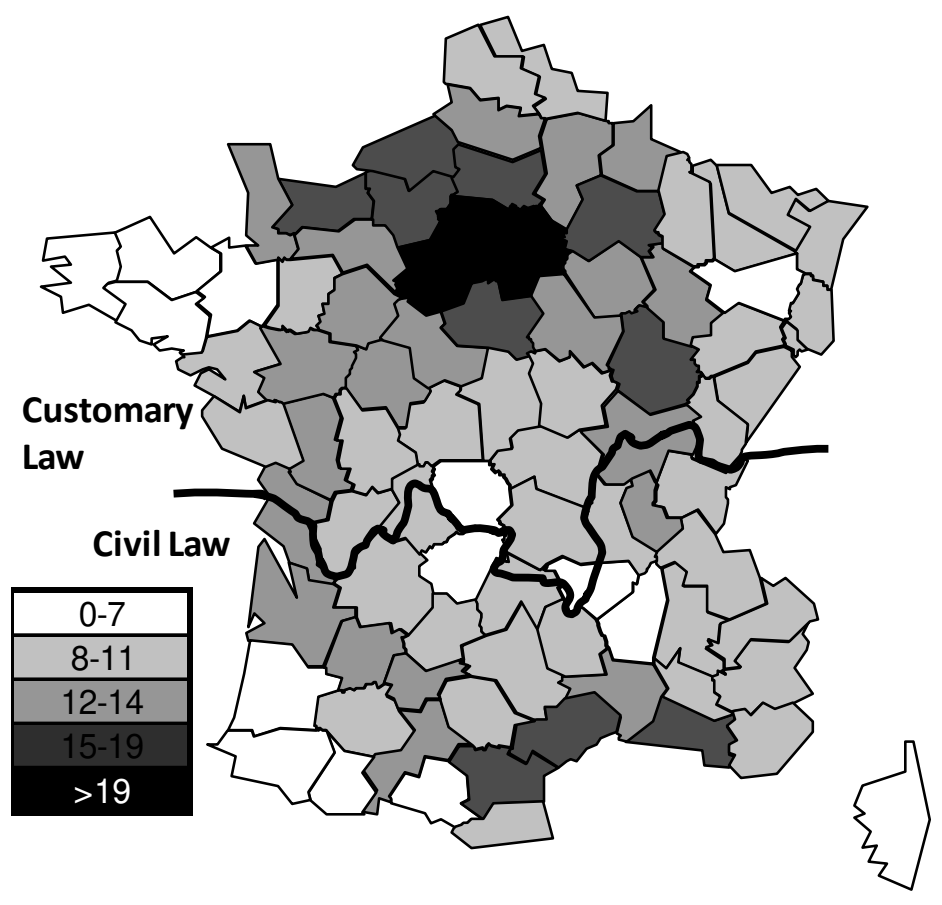

Figure 2, Map of TAX paid per capita in each Department

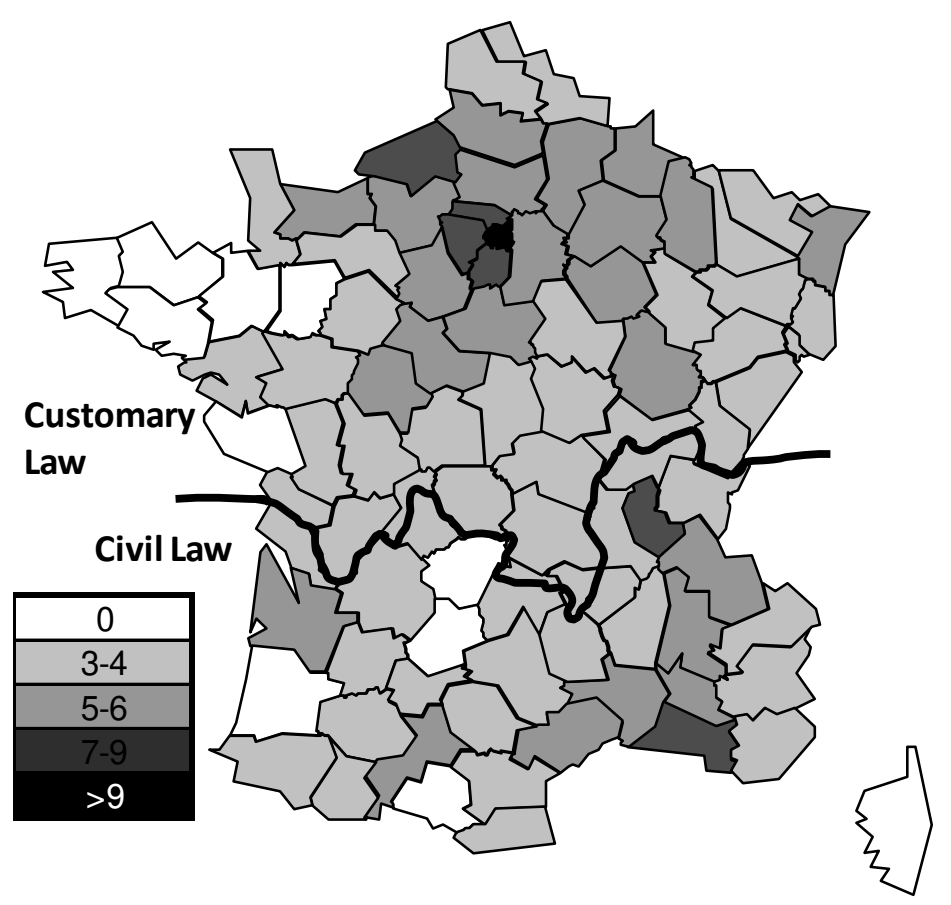

Figure 3, Map of CONTRACTS per capita in each Department 


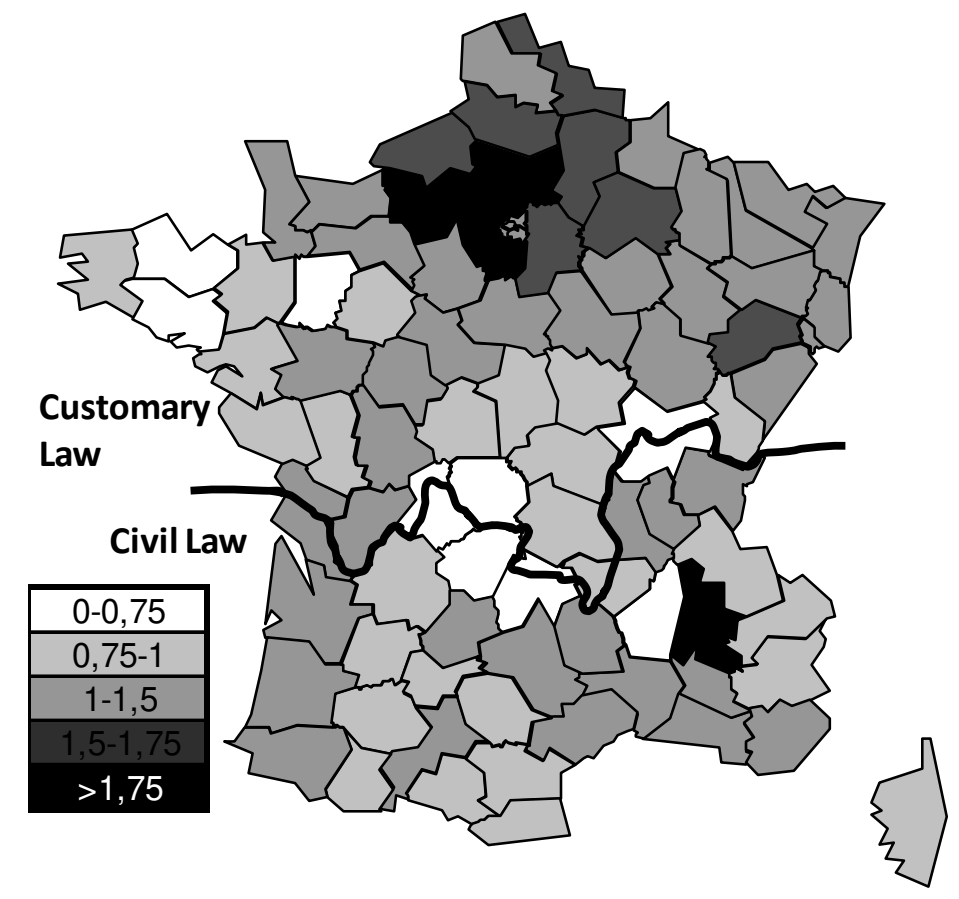

Figure 4, Map of DOORS AND WINDOWS per capita in each Department

Table 1. Descriptive statistics of our measures of economic development

\begin{tabular}{lcccccc}
\hline & Average & Mediane & Standard-Dev. & Minima & Maximum & Obs. \\
\hline TAX & 11,79 & 11,04 & 4,52 & 2,49 & 33,61 & 86 \\
CONTRACTS & 4,59 & 4,18 & 2,11 & 1,12 & 18,97 & 86 \\
DOORS AND WINDOWS & 1,10 & 1,04 & 0,31 & 0,60 & 1,94 & 86 \\
\hline
\end{tabular}

\section{Are civil law Departments less developed?}

We begin by observing the relationship between the legal regime and economic development. We compare the average of our three measures of economic development in the 31 Departments under civil law and the 48 under customary law ( 7 were both under civil and customary law). The Civil Law Departments exhibit weaker results according to our three measures of development (Table 2, Sample A). An inhabitant of a customary law Department paid on average $26.32 \%$ more TAX, CONTRACTS of $15.35 \%$ more value and enjoyed $14.51 \%$ more DOORS AND WINDOWS.

According to a T-test, these differences are significant at the $5 \%$ level, except for CONTRACTS. We first check if the higher development remains true after having weighted the averages by the population of each Department. Indeed, Departments are quite similar on the surface but not in terms of population; 905,764 people live in the Nord compared to only 121,418 in the Hautes-Alpes. Since civil law Departments are generally less populous, the previous observations are reinforced when adjusted for population. The differences between civil and customary Departments are higher and significant at $1 \%$ level except for CONTRACTS, which is however now significant at the $5 \%$ level (Table 2, Sample B). 
Furthermore, the difference between the two samples is accentuated by the two extreme cases. The richest Department (except for DOORS AND WINDOWS per capita) is Seine, which encompasses Paris. In a centralized country such as France, a significant part of the wealth of Paris should come from the administrative position of the city. On the other extreme, Corsica is the poorest Department (except in terms of DOORS AND WINDOWS per cap.) which could be explained by the insularity and the relatively complicated political situation (France bought Corsica from the Genoese in 1768) suffering several wars during the $18^{\text {th }}$ century. Thus, we measure these averages omitting Paris and Corsica as outliers. Excluding these two outliers, the differences strongly decrease and become nonsignificant (Table 2, Sample C).

Table 2. Economic development according to legal regime

\begin{tabular}{|c|c|c|c|c|c|}
\hline & $\begin{array}{c}\text { Customary } \\
\text { (1) }\end{array}$ & $\begin{array}{l}\text { Civil } \\
(2) \\
\end{array}$ & $\begin{array}{l}\text { Difference } \\
(1) \text { - (2) }\end{array}$ & $\begin{array}{c}\text { T-test } \\
\text { (p-value) }\end{array}$ & $\begin{array}{c}\text { Both } \\
\text { (3) }\end{array}$ \\
\hline \multicolumn{6}{|c|}{ Panel A: All sample } \\
\hline TAX & 12,98 & 10,27 & 2,70 & $0,0108 * *$ & 10,33 \\
\hline CONTRACTS & 4,90 & 4,25 & 0,65 & 0,1971 & 4,00 \\
\hline DOORS AND WINDOWS & 1,18 & 1,03 & 0,15 & $0,0324 * *$ & 0,85 \\
\hline \multicolumn{6}{|c|}{ Panel B: All sample weighted by population } \\
\hline TAX & 13,41 & 10,68 & 2,74 & $0,0002 * * *$ & 10,56 \\
\hline CONTRACTS & 5,24 & 4,45 & 0,79 & $0,0262 * *$ & 4,03 \\
\hline DOORS AND WINDOWS & 1,22 & 1,04 & 0,18 & $0,0003 * * *$ & 0,86 \\
\hline \multicolumn{6}{|c|}{ Panel C: Without Corse and Seine } \\
\hline TAX & 11,95 & 10,53 & 1,42 & 0,1039 & 10,33 \\
\hline CONTRACTS & 4,42 & 4,35 & 0,06 & 0,8536 & 4,00 \\
\hline DOORS AND WINDOWS & 1,14 & 1,04 & 0,10 & 0,1433 & 0,85 \\
\hline N. obs & 48 & 31 & & & 7 \\
\hline
\end{tabular}

\section{Does the legal regime explain the weaker development of civil law Departments?}

\section{Method}

To asses if the legal regime explains the disadvantage we observed in civil law Departments, we control for an array of other potential determinants of economic development. We consider the following cross-Departments regression:

$$
E_{i}=\beta_{0}+\beta_{1} \text { CIVILLAW }+\beta_{3} X_{i}+\varepsilon_{i}
$$

Where $E_{i}$ is a measure of economic performance for Department $i$ (log. of TAX paid per capita, log. of CONTRACTS per capita and log. of DOORS AND WINDOWS per capita), CIVIL LAW is the legal regime dummy variable, equal to one in civil law Departments, $X_{i}$ is a matrix of control variables for each Department (Distance from Paris, average altitude, presence of a Secondary Court...) and $\varepsilon_{i}$ is the error term. The control variables are exogenous fundamental factors that are suspected of 
explaining the differences in economic development. We exclude the Departments crossed by the customary/civil law boarder. We retain 79 observations. ${ }^{24}$

A negative and significant coefficient $\beta_{1}$ is interpreted as evidence for a negative impact from the CIVIL LAW regime on economic development.

\section{Does the legal regime explanation remain robust to climate?}

Climate is the oldest exogenous variable suspected of impacting the economic development of a Department. An early version of the geography hypothesis goes back to Montesquieu, who believed that climate, in particular heat, shaped human attitudes and motivation, which in turn affected economic outcomes. The direct effect of climate is verified by recent research, especially the negative effect of tropical locations (Sachs, 2001). ${ }^{25}$ The differences of climate within France are weak compared to international observations but could be strong enough to explain differences in economic development. We use the meteorological data (Météo France) from the Préfecture of each Department. The average maximum (TEMP. MAXIMUM) is 20.3 Celsius in the Department of Var versus only 12.6 in Nièvre. Similar differences are observed for the average minimum temperature (TEMP. MINIMUM), total rain in millimeters (RAIN) and number of hours of sun (SUN).

The results of Table 3 indicate that temperature and sun do not exhibit any correlation with our measures of economic development. But the quantity of RAIN over one year is negatively and significantly correlated with our three measures. A high quantity of RAIN is associated with poor Departments. This observation is theoretically consistent with a country such as France (it is probably different in arid regions). Accepting that each Department receives enough RAIN, a high level of RAIN leads to problems for agriculture and higher costs for land transport when roads were frequently dirt and unsurfaced. The dummy for CIVIL LAW always exhibits a negative coefficient i.e., civil law Departments are less economically developed. But this variable is non-significant in most of the specifications. The $R^{2}$ of the combinations of the legal regime and climate, as explanations for economic outcomes, is very low, leading to some doubts about the ability of these variables to explain the differences in economic performance across the Departments we observe.

\footnotetext{
${ }^{24}$ We exclude Cantal, Charente, Charente Inférieur, Haute Loire, Puy-de-Dôme, Saône-et-Loire and Haute Vienne.

${ }^{25}$ We don't use climatic and geographical variables as the source of the type institutions as proposed by the "endowment view" chaining natural endowments to colonization strategy, property rights and to the level of economic development (see Levine, 2005). This causal chain does not make sense for France.
} 
Table 3. Economic outcomes and legal regime controlled by climate

\begin{tabular}{|c|c|c|c|c|c|c|c|c|}
\hline & $\begin{array}{l}\text { Civil } \\
\text { Law } \\
\end{array}$ & $\begin{array}{l}\text { Temp. } \\
\text { Minimum }\end{array}$ & $\begin{array}{c}\text { Temp. } \\
\text { Maximum }\end{array}$ & $\begin{array}{l}\text { Rain } \\
\mathrm{mm}\end{array}$ & $\begin{array}{l}\text { Hours } \\
\text { of sun }\end{array}$ & Adjusted $\mathrm{R}^{2}$ & F test & Obs. \\
\hline \multirow[t]{5}{*}{ TAX } & $\begin{array}{c}-0,2677^{* * *} \\
(0,0055)\end{array}$ & $\begin{array}{c}0,0217 \\
(0,4725)\end{array}$ & & & & 0,0763 & 4,2225 & 79 \\
\hline & $\begin{array}{c}-0,2188^{*} \\
(0,0821)\end{array}$ & & $\begin{array}{l}-0,0074 \\
(0,8205)\end{array}$ & & & 0,0706 & 3,9635 & 79 \\
\hline & $\begin{array}{c}-0,2121^{* * *} \\
(0,0069)\end{array}$ & & & $\begin{array}{c}-0,0008^{* * *} \\
(0,0000)\end{array}$ & & 0,2611 & 14,7779 & 79 \\
\hline & $\begin{array}{c}-0,2934^{* *} \\
(0,0106)\end{array}$ & & & & $\begin{array}{c}0,0001 \\
(0,4610)\end{array}$ & 0,0767 & 4,2378 & 79 \\
\hline & $\begin{array}{l}-0,0360 \\
(0,7741)\end{array}$ & $\begin{array}{c}0,0411 \\
(0,2721)\end{array}$ & $\begin{array}{c}-0,0654 \\
(0,1230)\end{array}$ & $\begin{array}{c}-0,0009^{* * *} \\
(0,0000)\end{array}$ & $\begin{array}{c}-0,0001 \\
(0,5653)\end{array}$ & 0,2665 & 6,6678 & 79 \\
\hline \multirow[t]{5}{*}{ CONTRACTS } & $\begin{array}{l}-0,1036 \\
(0,3063)\end{array}$ & $\begin{array}{c}-0,0084 \\
(0,7956)\end{array}$ & & & & $-0,0046$ & 0,8210 & 79 \\
\hline & $\begin{array}{c}-0,0123 \\
(0,9261)\end{array}$ & & $\begin{array}{c}-0,036948834 \\
(0,2899)\end{array}$ & & & 0,0093 & 1,3662 & 79 \\
\hline & $\begin{array}{c}-0,0962 \\
(0,2769)\end{array}$ & & & $\begin{array}{c}-0,0006^{* *} \\
(0,0116)\end{array}$ & & 0,0759 & 4,2047 & 79 \\
\hline & $\begin{array}{l}-0,1525 \\
(0,2085)\end{array}$ & & & & $\begin{array}{c}0,0001 \\
(0,6297)\end{array}$ & $-0,0024$ & 0,9062 & 79 \\
\hline & $\begin{array}{c}0,0889 \\
(0,5379)\end{array}$ & $\begin{array}{c}0,0197 \\
(0,6454)\end{array}$ & $\begin{array}{l}-0,0806^{*} \\
(0,0988)\end{array}$ & $\begin{array}{c}-0,0007^{* * *} \\
(0,0078)\end{array}$ & $\begin{array}{c}0,0000 \\
(0,8680)\end{array}$ & 0,0838 & 2,4261 & 79 \\
\hline \multirow[t]{5}{*}{ DOORS AND WINDOWS } & $\begin{array}{c}-0,0916 \\
(0,1750)\end{array}$ & $\begin{array}{c}-0,0145 \\
(0,5020)\end{array}$ & & & & 0,0222 & 1,8839 & 79 \\
\hline & $\begin{array}{l}-0,0159 \\
(0,8561)\end{array}$ & & $\begin{array}{c}-0,0342 \\
(0,1407)\end{array}$ & & & 0,0442 & 2,8029 & 79 \\
\hline & $\begin{array}{l}-0,1024^{*} \\
(0,0920)\end{array}$ & & & $\begin{array}{l}-0,0003^{*} \\
(0,0988)\end{array}$ & & 0,0512 & 3,1034 & 79 \\
\hline & $\begin{array}{c}-0,1686^{* *} \\
(0,0375)\end{array}$ & & & & $\begin{array}{c}0,0001 \\
(0,2664)\end{array}$ & 0,0323 & 2,3005 & 79 \\
\hline & $\begin{array}{l}-0,0137 \\
(0,5379)\end{array}$ & $\begin{array}{c}0,0197 \\
(0,8448)\end{array}$ & $\begin{array}{c}-0,0675^{* *} \\
(0,0403)\end{array}$ & $\begin{array}{c}-0,0002 \\
(0,1251)\end{array}$ & $\begin{array}{c}0,0002 \\
(0,1397)\end{array}$ & 0,0930 & 2,5989 & 79 \\
\hline
\end{tabular}

Does the legal regime explanation remain robust to geography?

A contemporaneous strand of research explains international development by the direct impact of physical characteristics: countries being landlocked, distance from large markets or limited access to coasts and ocean navigable rivers (Sachs and Warner, 1997; Gallup et al., 1999; Malik and Temple, 2005). Geographical and climatic variables jointly account for $44 \%$ of contemporary variation in log current income using regressions across countries (Spolaore and Wacziarg, 2012). While geographical differences may not be as dramatic within France as across countries, they may still exert economic effects across Departments. We therefore test the robustness of the better economic outcomes of the customary Department including several geographical control variables.

Within France, all Departments do not benefit from a similar geography, providing exogenous advantages according to several physical characteristics. A first geographical advantage is the distance to the sea (KM TO SEA) measured as the number of kilometers between the Préfecture and the closest sea. Sea is at this time the best way to exchange thus, the further a Department is from the sea the less inhabitants can exchanged and specialize themselves in more advantageous activities. The positive effect of coast is empirically verified in the US (Rappaport and Sachs, 2003). But in our sample of French Departments (see Table 4), the KM TO SEA seems unable to explain any part of the difference in the development. 
This absence of a positive effect of the proximity of the sea could be due to another geographical advantage, which facilitated the exchange: the presence of navigable rivers. A navigable river provides about the same advantages in terms of exchange as the sea itself. Sokoloff (1988) shows that the patents per capita, used as a proxy for inventive activity are strongly and positively correlated with the proximity to navigable rivers. Some Departments are efficiently crossed by navigable RIVERS (up to $510 \mathrm{~km}$ ), whereas 17 others do not have a single kilometer of navigable river. We use the kilometers of navigable rivers only and not kilometers of canals, since the building of a canal in a Department could be a result of a prior development, thus would be endogenous. The result of the regressions (Table 4) exhibits a positive and significant relationship of RIVERS with our three measures of economic outcomes.

A third geographical characteristic able to influence development is the average altitude of each Department (ALTITUDE). A high average is the result of the presence of hills and mountains leading to more costly land exchanges and to more complicated general activity. The difference is huge between four Departments with an average ALTITUDE higher than 1,000 meters (up to 1,671 meters for Hautes-Alpes) and others being very flat. ${ }^{26}$ The coefficient of the variable ALTITUDE is negative but only significant in explaining the TAX paid per capita.

The main result of Table 4 is that the legal regime explanation is rarely robust to the geography according to our three measures of development. CIVIL LAW Departments do exhibit lower economic outcomes but this relationship is non-significant for most of our specifications. The legal regime is never significant after having controlled for the average ALTITUDE of the Department. The second important observation is that neither geography nor legal regime are able to explain a large part of the differences of development in the 79 French Departments. The maximum $\mathrm{R}^{2}$ we obtain is only 0.1777 .

\footnotetext{
${ }^{26}$ We reject the variable "surface of arable land per capita" since it depends on the number of inhabitants within each Department, which is not an independent factor form the Department's economic development.
} 
Table 4. Economic outcomes and legal regime controlled by geography

\begin{tabular}{|c|c|c|c|c|c|c|c|}
\hline & Civil Law & $\mathrm{Km}$ to sea & Rivers & Altitude & Adjusted $\mathrm{R}^{2}$ & F test & Obs. \\
\hline \multirow[t]{4}{*}{ TAX } & $\begin{array}{c}-0,2515^{* * *} \\
(0,0060)\end{array}$ & $\begin{array}{c}-0,0002 \\
(0,6345)\end{array}$ & & & 0,0728 & 4,0606 & 79 \\
\hline & $\begin{array}{c}-0,2381^{* * *} \\
(0,0052)\end{array}$ & & $\begin{array}{c}0,0000^{* *} \\
(0,0313)\end{array}$ & & 0,1254 & 6,5918 & 79 \\
\hline & $\begin{array}{l}-0,0784 \\
(0,4059)\end{array}$ & & & $\begin{array}{c}-0,0005^{* * *} \\
(0,0016)\end{array}$ & 0,0142 & 1,5607 & 79 \\
\hline & $\begin{array}{l}-0,0745 \\
(0,4926)\end{array}$ & $\begin{array}{c}0,0002 \\
(0,5953)\end{array}$ & $\begin{array}{c}0,0000 \\
(0,3648)\end{array}$ & $\begin{array}{c}-0,0005^{* *} \\
(0,0122)\end{array}$ & 0,1777 & 5,2152 & 79 \\
\hline \multirow[t]{4}{*}{ TRANSACTIONS } & $\begin{array}{l}-0,0776 \\
(0,4121)\end{array}$ & $\begin{array}{c}0,0005 \\
(0,1725)\end{array}$ & & & 0,0190 & 1,7544 & 79 \\
\hline & $\begin{array}{l}-0,1135 \\
(0,0052)\end{array}$ & & $\begin{array}{l}0,0000^{*} \\
(0,0927)\end{array}$ & & 0,0315 & 2,2666 & 79 \\
\hline & $\begin{array}{l}-0,0461 \\
(0,6656)\end{array}$ & & & $\begin{array}{c}-0,0002 \\
(0,2219)\end{array}$ & 0,0142 & 1,5607 & 79 \\
\hline & $\begin{array}{c}0,0173 \\
(0,8851)\end{array}$ & $\begin{array}{l}0,0007^{*} \\
(0,0793)\end{array}$ & $\begin{array}{c}0,0000 \\
(0,3132)\end{array}$ & $\begin{array}{l}-0,0003 \\
(0,2192)\end{array}$ & 0,0506 & 2,0382 & 79 \\
\hline \multirow[t]{4}{*}{ DOORS AND WINDOWS } & $\begin{array}{l}-0,1036 \\
(0,1069)\end{array}$ & $\begin{array}{c}0,0001 \\
(0,7021)\end{array}$ & & & 0,0182 & 1,7234 & 79 \\
\hline & $\begin{array}{c}-0,1097^{*} \\
(0,0676)\end{array}$ & & $\begin{array}{c}0,0000^{* *} \\
(0,0350)\end{array}$ & & 0,0725 & 4,0502 & 79 \\
\hline & $\begin{array}{l}-0,0652 \\
(0,4059)\end{array}$ & & & $\begin{array}{l}-0,0001 \\
(0,2256)\end{array}$ & 0,0353 & 2,4251 & 79 \\
\hline & $\begin{array}{c}0,0173 \\
(0,8851)\end{array}$ & $\begin{array}{l}-0,0721 \\
(0,0002)\end{array}$ & $\begin{array}{c}0,0000 \\
(0,1023)\end{array}$ & $\begin{array}{c}-0,0001 \\
(0,5521)\end{array}$ & 0,0541 & 2,1161 & 79 \\
\hline
\end{tabular}

Does the legal regime explanation remain robust to long-term political factors?

A third category of factors can potentially explain the level of development of a Department: the long-term effect of political factors mainly inherited from the hazard of historical events. The first manifestation of the existence of a political community is the frontier. The French frontiers are exogenous results of war, marriages and settlement of estates. We could suspect that the Departments on the FRONTIER might have suffered from limitation of exchanges or specific taxes. The variable FRONTIER is a dummy variable, equal to one for the borderer Departments. FRONTIER appears to be significantly negative in only one specification and exhibits several cases of positive coefficients.

A second administrative variable is the presence of one PARLIAMENT. In Old Regime France, a PARLIAMENT is the Supreme Court presiding over one legal area. Several administrative authorities are associated with the presence of a PARLIAMENT in a city. These multiple administrations take advantages of revenues coming from all the area which they control. We assume the presence of a PARLIAMENT is an exogenous variable since the location of one PARLIAMENT is the result of the hazard of history. They are mainly established in a former fiefdom of local lords who took power before being attached to the kingdom of France. They are often in big cities, but not always. For example, Trévoux has a PARLIAMENT despite being a small city (but the origin of a previously powerful dynasty) and Lyon, the second city of the country, does not have a PARLIAMENT. Thus, this dummy for PARLIAMENT partially captures the presence of big cities but not solely. 14 PARLIAMENTS 
existed under the Old Regime. ${ }^{27}$ This dummy appears to be significantly associated with the economic development in all the specifications. Regressions including this variable show an $R$ squared always above 0.10 (Table 5).

A last administrative variable is the distance from Paris (KM TO PARIS), measured as the crow flies from Paris to the Préfecture of the Department. Since Paris is the capital of the country, the distance from the capital reduces the opportunity to influence state decisions and profit from tax redistribution. The presence of the capital in Paris is exogenous since it is the result of the victory of a minor Frankish King, Clovis, whose armies drove away Roman soldiers from the city, which was not a Roman capital. Then, the successive military success of this kingdom over centuries brought about Paris' status as the capital of the large territory we study in this paper. The KM TO PARIS is highly significant in all specifications to explain lower levels of economic development.

Controlling for these political variables, Table 5 reveals that CIVIL LAW Departments exhibit significant negative coefficients in only two specifications, explaining the level of TAX paid. More important, three other cases exhibit significant coefficients, but with a positive impact from civil law. Explaining the CONTRACTS per capita by the KM TO PARIS and by the combination of these political factors, the dummy for CIVIL LAW is positive and significant. A similar positive and significant coefficient is found for the CIVIL LAW dummy when the number of DOORS AND WINDOWS is explained by the KM TO PARIS. These three cases are interesting because they show a positive and significant effect of CIVIL LAW after the control for the variable, which is always highly significant (which is the KM TO PARIS). The R squared of the regression, explaining CONTRACTS by the combination of these political factors, rises to 0.28 . These three specifications show results clearly inconsistent with law and finance theory.

\footnotetext{
${ }^{27}$ Paris, Toulouse, Bordeaux, Grenoble, Dijon, Rouen, Aix, Trévoux, Rennes, Pau, Metz, Douai, Besançon, and Nancy.
} 
Table 5. Economic outcomes and legal regime controlled by long-term administrative factors

\begin{tabular}{|c|c|c|c|c|c|c|c|}
\hline & Civil Law & Frontier & Parliament & $\begin{array}{c}\mathrm{Km} \text { from } \\
\text { Paris }\end{array}$ & Adjusted $\mathrm{R}^{2}$ & F test & Obs. \\
\hline \multirow[t]{4}{*}{ TAX } & $\begin{array}{c}-0,2456 * * * \\
(0,0047)\end{array}$ & $\begin{array}{l}-0,1659 \\
(0,1520)\end{array}$ & & & 0,0949 & 5,0901 & 79 \\
\hline & $\begin{array}{c}-0,2351^{* * *} \\
(0,0058)\end{array}$ & & $\begin{array}{c}0,1905^{* *} \\
(0,0334)\end{array}$ & & 0,1241 & 6,5252 & 79 \\
\hline & $\begin{array}{c}0,0600 \\
(0,5953)\end{array}$ & & & $\begin{array}{c}-0,0010^{* * *} \\
(0,0004)\end{array}$ & 0,2131 & 11,5624 & 79 \\
\hline & $\begin{array}{c}0,0725 \\
(0,4972)\end{array}$ & $\begin{array}{c}-0,2054^{* *} \\
(0,0484)\end{array}$ & $\begin{array}{c}0,2482^{* * *} \\
(0,0027)\end{array}$ & $\begin{array}{c}-0,0010^{* * *} \\
(0,0001)\end{array}$ & 0,3032 & 9,4844 & 79 \\
\hline \multirow[t]{4}{*}{ CONTRACTS } & $\begin{array}{l}-0,1135 \\
(0,2184)\end{array}$ & $\begin{array}{c}0,0293 \\
(0,8142)\end{array}$ & & & $-0,0048$ & 0,8149 & 79 \\
\hline & $\begin{array}{l}-0,1083 \\
(0,2124)\end{array}$ & & $\begin{array}{c}0,2824^{* * *} \\
0,28 \%\end{array}$ & & 0,1065 & 5,6505 & 79 \\
\hline & $\begin{array}{l}0,2135^{*} \\
(0,0789)\end{array}$ & & & $\begin{array}{c}-0,0011^{* * *} \\
(0,0003)\end{array}$ & 0,1566 & 8,2419 & 79 \\
\hline & $\begin{array}{c}0,2462^{* *} \\
(0,0304)\end{array}$ & $\begin{array}{l}-0,0240 \\
(0,8237)\end{array}$ & $\begin{array}{c}0,3184^{* * *} \\
(0,0003)\end{array}$ & $\begin{array}{c}-0,0012^{* * *} \\
(0,0000)\end{array}$ & 0,2765 & 8,4506 & 79 \\
\hline \multirow[t]{4}{*}{ DOORS AND WINDOWS } & $\begin{array}{l}-0,1080 \\
(0,2184)\end{array}$ & $\begin{array}{c}0,0293 \\
(0,8142)\end{array}$ & & & $-0,0048$ & 0,8149 & 79 \\
\hline & $\begin{array}{l}-0,1073 \\
(0,2124)\end{array}$ & & $\begin{array}{c}0,1439 * * * \\
(0,0028)\end{array}$ & & 0,1065 & 5,6505 & 79 \\
\hline & $\begin{array}{l}0,0356^{*} \\
(0,0789)\end{array}$ & & & $\begin{array}{c}-0,0011^{* * *} \\
(0,0003)\end{array}$ & 0,0871 & 4,7198 & 79 \\
\hline & $\begin{array}{c}0,0550 \\
(0,5031)\end{array}$ & $\begin{array}{l}-0,0240 \\
(0,8237)\end{array}$ & $\begin{array}{c}0,3184^{* *} \\
(0,0152)\end{array}$ & $\begin{array}{c}-0,0005^{* * *} \\
(0,0076)\end{array}$ & 0,1449 & 4,3057 & 79 \\
\hline
\end{tabular}

Does the legal regime explanation remain robust to religion and knowledge?

A last set of regressions is run to control for the impact of the legal regime by cultural effects, namely Protestantism and distance to knowledge. ${ }^{28}$ Protestantism is one of the classical cultural institutions that have been presented as favorable to economic development since Weber (1930). Stulz and Williamson (2003) update the work of Weber (1930) arguing that British legal origin countries are primarily Protestant, while French legal origin countries are overwhelmingly Catholic. They argue that legal origin proxies for religious and cultural differences that influence financial development and that difference in legal tradition, per se, is not crucial for explaining current levels of financial development. Stulz and Williamson (2003) identify three channels through which culture can influence economic outcomes: values of the society, institutions and resource allocation. We can suppose that the percentage of Protestants in modern France was not enough to influence institutions, but the two other channels may have a potential impact in Departments with a large Protestant community.

\footnotetext{
${ }^{28}$ We also explored the potential negative effect of the Napoleonic wars on the economic development of one Department. We used Vallée (1956) which reproduces the tables measuring population and number of conscripts per Department from the military administration of the Empire (not reproduced in the paper). The percentage of conscripts is positively correlated with the economic development. Indeed, the conscription was stronger in Departments rich enough to provide soldiers whereas poor areas (such as Britany) were partially exempted. Due to this endogeneity, it is not possible to control for a potential negative effect of the Napoleonic wars.
} 
France is an excellent laboratory to test the positive effect of Protestantism since important protestant populations were concentrated in several areas since the $16^{\text {th }}$ century. Despite terrible Religious wars and the huge emigration of Huguenots to northern Europe, a large protestant community remained established in France up to the $20^{\text {th }}$ century. We do not have high quality data for the presence of Protestants before the $19^{\text {th }}$ century, thus we use the $\%$ OF PROTESTANT in each Department as measured by the census of 1866 . We assume this figure is a correct proxy for the presence of Protestants for centuries, which is confirmed by the historical narrative (Cabanel, 2012) and a second series of the 274 places allowed for Protestants in 1620 (de Dainville, 1968). ${ }^{29}$ There is substantial cross-Department variation in the \% OF PROTESTANT in the population, ranking from $0 \%$ in several Departments up to $30.77 \%$ in Bas-Rhin (Alsace) and $28.66 \%$ in Gard (Cévennes). If several protestant families, such as Peugeot, are known to have been successful entrepreneurs, other Protestant communities, such as in Cevennes, remained underdeveloped. LLSV (1999) and Beck et al. $(2000,2001)$ also use the fraction of a population that practices a given religion in the multiple regressions in their international studies. The \% OF PROTESTANT is never significant to explain the economic outcomes among Departments, with sometimes a negative coefficient (Table 6). This absence of relation between Protestantism and economic development confirms Delacroix and Nielsen (2001); they conclude that Weber's purported link between Protestantism and economic outcome is a "myth". Becker and Woessmann (2009) do not find a positive effect of the specific ethic of Protestantism in Prussian counties after having controlled for literacy.

A last variable we use is a measure of the access to knowledge through the distance in kilometers of each Préfecture to the closest university (KM TO UNIVERSITY). 21 universities were created in France between 1215 and 1538 to teach especially law. ${ }^{30}$ We can therefore expect a positive effect of a university, to spread knowledge, especially law, and to improve economic relations. The closest university sometimes corresponds to the closest important city, but not always. As an example, the small city of Cahors lodges a university founded in 1331 because the Pope John XXII was born in this city. On the other hand, the big city of Lyon does not have a university before the $20^{\text {th }}$ century. This variable is always highly significant with the expected sign strongly increasing the R squared (Table $6)$.

Consistent with legal origin theory, the CIVIL LAW dummy exhibits negative coefficients after control for \% OF PROTESTANT and KM TO UNIVERSITY. But, this coefficient is significant only when TAX paid is explained. CONTRACTS and DOORS AND WINDOWS are not robust to the controls even if a negative sign is associated with Departments under the civil law.

\footnotetext{
${ }^{29}$ We count the number of places in each modern Department. Many Departments do not have a single place when the maximum is 30 in the Gard. This second series exhibit a correlation of 0.75 with the series of the census of Protestants in 1866. Thus, the use of this second series does not change our results.

30 Paris in 1215, then Toulouse, Montpellier, Avignon, Orléans, Cahors, Grenoble, Angers, Orange, Aix, Besançon, Poitiers, Caen, Bordeaux, Valence, Nantes, Bourges, Reims, Douai, Nancy and Strabourg in 1538.
} 
Table 6. Economic outcomes and legal regime controlled by Protestantism and knowledge

\begin{tabular}{|c|c|c|c|c|c|c|}
\hline & Civil Law & $\begin{array}{c}\% \text { of } \\
\text { Protestant } \\
\end{array}$ & $\begin{array}{c}\mathrm{Km} \text { to } \\
\text { University }\end{array}$ & Adjusted $\mathrm{R}^{2}$ & F test & Obs. \\
\hline \multirow[t]{3}{*}{ TAX } & $\begin{array}{c}-0,2372 * * * \\
(0,0073)\end{array}$ & $\begin{array}{r}-0,1520 \\
(0,8452)\end{array}$ & & 0,0705 & 3,9561 & 79 \\
\hline & $\begin{array}{c}-0,2019 * * * \\
(0,0078)\end{array}$ & & $\begin{array}{c}-0,0034^{* * *} \\
(0,0000)\end{array}$ & 0,3108 & 18,5862 & 79 \\
\hline & $\begin{array}{c}-0,1857^{* *} \\
(0,0145)\end{array}$ & $\begin{array}{r}-0,9636 \\
(0,1610)\end{array}$ & $\begin{array}{c}-0,0036^{* * *} \\
(0,0000)\end{array}$ & 0,3198 & 13,2226 & 79 \\
\hline \multirow[t]{3}{*}{ CONTRACTS } & $\begin{array}{r}-0,1290 \\
(0,1615)\end{array}$ & $\begin{array}{c}1,0023 \\
(0,2270)\end{array}$ & & 0,0138 & 1,5437 & 79 \\
\hline & $\begin{array}{r}-0,0726 \\
(0,3534)\end{array}$ & & $\begin{array}{c}-0,0038^{* * *} \\
(0,0000)\end{array}$ & 0,2798 & 16,1480 & 79 \\
\hline & $\begin{array}{l}-0,0751 \\
(0,3455)\end{array}$ & $\begin{array}{c}0,1535 \\
(0,8331)\end{array}$ & $\begin{array}{c}-0,0038^{* * *} \\
(0,0000)\end{array}$ & 0,2706 & 10,6449 & 79 \\
\hline \multirow[t]{3}{*}{ DOORS AND WINDOWS } & $\begin{array}{c}-0,1190 * \\
(0,0546)\end{array}$ & $\begin{array}{c}0,5904 \\
(0,2863)\end{array}$ & & 0,0310 & 2,2481 & 79 \\
\hline & $\begin{array}{l}-0,0920 \\
(0,3534)\end{array}$ & & $\begin{array}{c}-0,0017^{* * *} \\
(0,0015)\end{array}$ & 0,1389 & 7,2914 & 79 \\
\hline & $\begin{array}{c}-0,0751 \\
(0,1047)\end{array}$ & $\begin{array}{c}0,2229 \\
(0,6778)\end{array}$ & $\begin{array}{c}-0,0016^{* * *} \\
(0,0027)\end{array}$ & 0,1294 & 4,8661 & 79 \\
\hline
\end{tabular}

Does the legal regime explanation remain robust to a combination of control variables?

Since the previous regressions of several kinds of variables exhibit diverging results regarding both the impact and the significance of CIVIL LAW, a combination of control variables along with CIVIL LAW are added together to account for their joint influence on economic development. We retain the six variables which have proved to have been able to explain our measures of development as a single control for the legal regime. We thus use RAIN, RIVERS, ALTITUDE, PARLIAMENT, KM TO PARIS and KM TO UNIVERSITY. Table 7 shows the results of these regressions. KM TO PARIS and KM TO UNIVERSITY are significantly correlated with our three measures of economic development with the expected (negative) sign. The adjusted R-square are relatively high $(>0.4)$ except when explaining DOORS AND WINDOWS per capita). Furthermore, when adding the CIVIL LAW dummy variable to the regressions, the adjusted R-square only weakly rises, or even decreases.

More important, all results converge to find a positive coefficient of CIVIL LAW, contradicting legal origin theory; economic development is higher for CIVIL LAW Departments after having controlling for these six variables. This positive coefficient is significant at the $5 \%$ level in explaining the value of CONTRACTS per capita. This unexpected observation of a positive effect of CIVIL LAW warrants further investigation. 
Table 7. Economic outcomes and legal regime controlled by a combination of factors.

\begin{tabular}{|c|c|c|c|c|c|c|c|c|c|c|}
\hline & Civil Law & Rain & Rivers & Altitude & Parliament & $\begin{array}{l}\mathrm{Km} \text { to } \\
\text { Paris }\end{array}$ & $\begin{array}{c}\mathrm{Km} \text { to } \\
\text { University }\end{array}$ & Adjusted $\mathrm{R}^{2}$ & F test & Obs. \\
\hline \multirow[t]{2}{*}{ TAX } & & $\begin{array}{c}-0,0006^{* *} \\
(0,0002)\end{array}$ & $\begin{array}{l}0,0000 \\
78,90 \%\end{array}$ & $\begin{array}{l}-0,0002^{*} \\
(0,0531)\end{array}$ & $\begin{array}{c}0,0392 \\
(0,5821)\end{array}$ & $\begin{array}{c}-0,0006^{* * *} \\
(0,0007)\end{array}$ & $\begin{array}{c}-0,0026^{* * *} \\
(0,0000)\end{array}$ & 0,5412 & 16,3336 & 79 \\
\hline & $\begin{array}{c}0,1457 \\
(0,1349)\end{array}$ & $\begin{array}{c}-0,0006^{* * *} \\
(0,0004)\end{array}$ & $\begin{array}{c}0,0000 \\
(0,8062)\end{array}$ & $\begin{array}{c}-0,0003^{* * *} \\
(0,0173)\end{array}$ & $\begin{array}{c}0,0516 \\
(0,4690)\end{array}$ & $\begin{array}{c}-0,0008^{* * *} \\
(0,0005)\end{array}$ & $\begin{array}{c}-0,0026 * * * \\
(0,0000)\end{array}$ & 0,5492 & 14,5770 & 79 \\
\hline \multirow[t]{2}{*}{ CONTRACTS } & & $\begin{array}{c}-0,0003^{*} \\
(0,0828)\end{array}$ & $\begin{array}{c}0,0000 \\
(0,9607)\end{array}$ & $\begin{array}{c}0,0001 \\
(0,3767)\end{array}$ & $\begin{array}{c}0,1795^{* *} \\
(0,0337)\end{array}$ & $\begin{array}{c}-0,0007 * * * \\
(0,0007)\end{array}$ & $\begin{array}{c}-0,0030^{* * *} \\
(0,0000)\end{array}$ & 0,4097 & 10,0216 & 79 \\
\hline & $\begin{array}{c}0,2521^{* *} \\
(0,0254)\end{array}$ & $\begin{array}{c}-0,0003 \\
(0,1464)\end{array}$ & $\begin{array}{c}0,0000 \\
(0,4231)\end{array}$ & $\begin{array}{c}0,0000 \\
(0,8880)\end{array}$ & $\begin{array}{c}0,2008^{* *} \\
(0,0157)\end{array}$ & $\begin{array}{c}-0,0010^{* * *} \\
(0,0001)\end{array}$ & $\begin{array}{c}-0,0030^{* * *} \\
(0,0000)\end{array}$ & 0,4423 & 9,8376 & 79 \\
\hline \multirow[t]{2}{*}{ DOORS AND WINDOWS } & & $\begin{array}{c}-0,0001 \\
(0,3114)\end{array}$ & $\begin{array}{c}0,0000 \\
(0,4483)\end{array}$ & $\begin{array}{c}0,0000 \\
(0,8986)\end{array}$ & $\begin{array}{c}0,0865 \\
(0,1895)\end{array}$ & $\begin{array}{c}-0,0004^{* *} \\
(0,0170)\end{array}$ & $\begin{array}{c}-0,0012^{* *} \\
(0,0361)\end{array}$ & 0,1946 & 4,1412 & 79 \\
\hline & $\begin{array}{c}0,0364 \\
(0,6871) \\
\end{array}$ & $\begin{array}{r}-0,0001 \\
(0,3473) \\
\end{array}$ & $\begin{array}{r}0,0000 \\
(0,5632) \\
\end{array}$ & $\begin{array}{r}0,0000 \\
(0,9550) \\
\end{array}$ & $\begin{array}{c}0,0895 \\
(0,1798) \\
\end{array}$ & $\begin{array}{c}-0,0004^{* *} \\
(0,0411)\end{array}$ & $\begin{array}{c}-0,0012^{* *} \\
(0,0365)\end{array}$ & 0,1851 & 3,5317 & 79 \\
\hline
\end{tabular}

\section{Are the Civil law Departments less financially developed?}

The first prediction of law and finance theory is that differences in legal regime can explain international differences in financial development. Furthermore, there is a substantial body of work suggesting that a high level of financial development promotes economic growth (Pasali, 2013). We previously assumed that the two causal relationships have been in action, since French legal regimes were enforced for centuries: better legal regime $\rightarrow$ higher financial development $\rightarrow$ better economic outcomes. Thus, we have used our three variables measuring both economic and financial development.

Since the relationship between legal regime and economic outcomes is not verified and even at times appears to be the reverse of what was expected, we go back to the first prediction of the legal origin theory, testing only: better legal regime $\rightarrow$ higher financial development. Thus, in this section, we only focus on financial development as measured by the amount of contracts per capita (CONTRACTS). To test if civil law is really unfavorable to financial development, we use the two other variables of economic outcomes (TAX and DOORS AND WINDOWS) as control variables for the dummy variable CIVIL LAW. We run the regression thereafter to explain the CONTRACT per capita using several specifications, i.e. between one and three explicative variables. These regressions answer the question: are the CIVIL LAW Departments less financially developed after controlling for the general wealth?

$$
\operatorname{CONTRACT}_{i}=\beta_{0}+\beta_{1} \text { CIVIL LAW }+\beta_{3} \text { TAX }_{i}+\beta_{4} \text { DOORS AND WINDOWS } i+\varepsilon_{i}
$$

Table 8 provides the results of these regressions. It is not a surprise to observe that the amount of CONTRACTS per capita is heavily influenced by the economic development measured by the TAX paid per capita and the number of DOORS AND WINDOWS per capita. The R-squared is approximately 0.74. Adding the dummy for CIVIL LAW Departments weakly improves the R-squared to 0.75 . We do find a significant impact of CIVIL LAW, but observe a positive sign. Thus, controlling for the general level of development, the CIVIL LAW regime leads to a higher CONTRACTS per capita. This result is not consistent with legal origin theory. 
Table 8. Financial development controlled by economic outcomes.

\begin{tabular}{|c|c|c|c|c|c|c|}
\hline & $\begin{array}{l}\text { CIVIL } \\
\text { LAW }\end{array}$ & TAX & $\begin{array}{l}\text { DOORS AND } \\
\text { WINDOWS }\end{array}$ & Adjusted $\mathrm{R}^{2}$ & F test & Obs. \\
\hline \multirow[t]{4}{*}{ CONTRACTS } & $\begin{array}{c}0,0984^{* * *} \\
(0,0691)\end{array}$ & $\begin{array}{c}0,8898^{* * *} \\
(0,0000)\end{array}$ & & 0,4891 & 38,3313 & 79 \\
\hline & $\begin{array}{c}0,0017 \\
(0,9798)\end{array}$ & & $\begin{array}{c}1,0519 * * * \\
(0,0000)\end{array}$ & 0,4891 & 38,3313 & 79 \\
\hline & & $\begin{array}{c}0,6480^{* * *} \\
(0,0000)\end{array}$ & $\begin{array}{c}0,4713 * * * \\
(0,0000)\end{array}$ & 0,7386 & 111,2189 & 79 \\
\hline & $\begin{array}{c}0,1022^{* *} \\
(0,0358)\end{array}$ & $\begin{array}{c}0,6863 * * * \\
(0,0000)\end{array}$ & $\begin{array}{c}0,4754^{* * *} \\
(0,0000)\end{array}$ & 0,7504 & 79,1523 & 79 \\
\hline
\end{tabular}

This counter intuitive result requires further explanations. First, the CIVIL LAW regime could be fundamentally better than the customary law regime in regards to the propensity to contract. The written nature of CIVIL LAW lowers the transaction costs by reducing the uncertainty thanks to a stable legal context and the standardizing of contracts. An unexplored effect of the current legal regime is the cost of justice which represents today $2.6 \%$ of the US GDP versus only 0.6 in France or 0.8 in Switzerland (Association Henri Capitan, 2006). Second, the higher propensity to contract using a notary could be an old path dependency because the notarial activity originated from Italy, diffusing more quickly in southern France than in the North. Third, a reversal effect could be imagined, the uncertainty in the southern institutions leads to the use a notary to record contracts more frequently than in the north. Fourth, our measure could be biased by the effect of the Revolution, which affected the credit market in the north more strongly than in the south. The inflation of the assignats allowed borrowers to reimburse perpetual annuities in devaluated money. This effect was not homogenous across France, since the perpetual annuity (rente) was the dominant financial tool, $60 \%$ of the loans, in northern France compared to only $36.6 \%$ in the south (Hoffman et al., 2004). Our data of CONTRACTS per capita could still be biased by this phenomenon even if the assignats episode was 27 years before the data were created.

This rejection of legal origin theory within Old Regime France joins various researches. Empirical historical studies reject the consequence of legal origin theory: Rajan and Zingales (2003) and Musacchio (2008) find that, French civil law countries exhibit higher financial development before the First World War. Other researches do not observe that the legal environment is more favorable to the financial development in common law countries. Measuring the changes in the rules over time for several countries, Armour et al. (2009) cast some doubts on the plausibility of the mechanisms that have been said to underpin the links posited between legal origins and financial development. Comparing the business law in France and the United States during the $19^{\text {th }}$, it is found that the contracting environment in the United States was neither freer nor more flexible than in France (Lamoreaux and Rosenthal, 2005). According to the companies traded on the Milan stock exchange during the $20^{\text {th }}$ century, Aganin and Volpin (2003) argue that the corporate ownership in Italy does not provide strong support for the law and finance view. Franks et al. (2003) stress that it was not until 1980 that English Parliament enacted strong minority shareholder rights statutes. Using 51 bankruptcy laws from 15 countries during the $19^{\text {th }}$ century, Sgard (2006) does not observe a determinant effect of legal origin. 


\section{Robustness checks on sample used}

We again run the test of the effect of the legal regime controlled by a combination of factors (Table 7) and the test of the financial development controlled by economic outcomes (Table 8) which are our two most demonstrative regressions using two different samples.

Are the results robust to the exclusion of two outliers?

We exclude the two extreme cases which are Corse and Seine for the reasons explained in section 3. The main conclusion of our test on our three measures of economic outcomes remains similar after the omission of Seine and Corse. Contradicting the legal origin theory, the CIVIL LAW Departments exhibit higher economic outcomes. But, this difference is only significant for our measure of CONTRACTS per capita (Table 9, Sample A).

The test of the financial development (CONTRACTS) controlled by the economic outcomes (TAX and DOORS AND WINDOWS) excluding Seine and Corse also confirms previous results (Table 10, Sample A). After having controlled for the wealth of a Department, the CIVIL LAW areas exhibit a higher inclination to contract according to the amount of taxes paid on contracts recorded by notaries. This figure is significant at the $5 \%$ level.

\section{Do the results remain robust to the effect of the legal frontier?}

We can suspect that our observations of the impact of legal regime on development are biased by noisy data. Departments bordering the frontier between civil and customary regimes could suffer cross-influence due to the diffusion of both peoples and institutions from the two sides of the boarder. We have historical evidence of the diffusion of civil law: seven customs close to the limit of customary law country has been influenced by Roman law, especially accepting Roman law when the custom is unclear (Chénon, 1929). ${ }^{31}$ To control for this potential noise in the data, we exclude all the Departments bordering the frontier: three Departments of customary law bordering civil law country and five Department of civil law bordering customary law country. ${ }^{32}$

This sample confirms the previous results. For our three measures of economic performance, the CIVIL LAW dummy obtains a positive coefficient which is significant at $5 \%$ level for CONTRATCS per capita only. Using TAX and DOORS AND WINDOWS per capita to explain the CONTRACTS per capita, the regression on the sample without bordering Departments shows a similar positive and significant coefficient.

\footnotetext{
${ }^{31}$ It was the case of the customs of Berry, Haute-Marche, Auvergne, Bourbonnais, Bourgogne, Franche-Comté and Trois-Evéchés.

${ }^{32}$ Creuse, Allier, Jura and Dordogne for the custumary area Corrèze, Lozère, Loire and Ain for the civil area.
} 
Table 9. Economic outcomes and legal regime controlled by a combination of factors on different samples

\begin{tabular}{|c|c|c|c|c|c|c|c|c|c|c|}
\hline & Civil Law & Rain & Rivers & Altitude & Parliament & $\begin{array}{l}\mathrm{Km} \text { to } \\
\text { Paris }\end{array}$ & $\begin{array}{c}\mathrm{Km} \text { to } \\
\text { University }\end{array}$ & Adjusted $\mathrm{R}^{2}$ & F test & Obs. \\
\hline \multicolumn{11}{|c|}{ Sample A : Wihout Seine and Corse } \\
\hline TAX & $\begin{array}{c}0,0715 \\
(0,4325)\end{array}$ & $\begin{array}{c}-0,0007^{* * *} \\
(0,0000)\end{array}$ & $\begin{array}{c}0,0000 \\
(0,5749)\end{array}$ & $\begin{array}{c}-0,0003^{* *} \\
(0,0162)\end{array}$ & $\begin{array}{c}0,0199 \\
(0,7658)\end{array}$ & $\begin{array}{c}-0,0004^{* *} \\
(0,0439)\end{array}$ & $\begin{array}{c}-0,0013^{* *} \\
(0,0538)\end{array}$ & 0,4697 & 10,6163 & 79 \\
\hline CONTRACTS & $\begin{array}{c}0,1850 * * \\
(0,0858)\end{array}$ & $\begin{array}{c}-0,0003 * \\
(0,0653)\end{array}$ & $\begin{array}{c}0,0000 \\
(0,8996)\end{array}$ & $\begin{array}{c}0,0000 \\
(0,9455)\end{array}$ & $\begin{array}{c}0,1511^{*} \\
(0,0561)\end{array}$ & $\begin{array}{c}-0,0007 * * * \\
(0,0038)\end{array}$ & $\begin{array}{c}-0,0023 * * * \\
(0,0036)\end{array}$ & 0,2851 & 5,3301 & 79 \\
\hline DOORS AND WINDOWS & $\begin{array}{c}0,0554 \\
(0,5496)\end{array}$ & $\begin{array}{r}-0,0001 \\
(0,6081)\end{array}$ & $\begin{array}{c}0,0000 \\
(0,6953)\end{array}$ & $\begin{array}{c}0,0000 \\
(0,9471)\end{array}$ & $\begin{array}{c}0,0890 \\
(0,1917)\end{array}$ & $\begin{array}{c}-0,0005^{* *} \\
(0,0220)\end{array}$ & $\begin{array}{c}-0,0017^{* *} \\
(0,0140)\end{array}$ & 0,1787 & 3,3630 & 79 \\
\hline \multicolumn{11}{|c|}{ Sample B : Wihout Départements bordering the frontier } \\
\hline TAX & $\begin{array}{c}0,1724 \\
(0,1244)\end{array}$ & $\begin{array}{c}-0,0006^{* * *} \\
(0,0019)\end{array}$ & $\begin{array}{c}0,0000 \\
(0,8474)\end{array}$ & $\begin{array}{c}-0,0003^{* *} \\
(0,0216)\end{array}$ & $\begin{array}{c}0,0514 \\
(0,5082)\end{array}$ & $\begin{array}{c}-0,0008^{* * *} \\
(0,0007)\end{array}$ & $\begin{array}{c}-0,0025^{* * *} \\
(0,0003)\end{array}$ & 0,5304 & 12,2935 & 79 \\
\hline CONTRACTS & $\begin{array}{c}0,3082^{* *} \\
(0,0178)\end{array}$ & $\begin{array}{r}-0,0002 \\
(0,2250)\end{array}$ & $\begin{array}{c}0,0000 \\
(0,4592)\end{array}$ & $\begin{array}{c}0,0000 \\
(0,7746)\end{array}$ & $\begin{array}{c}0,1990 * * \\
(0,0277)\end{array}$ & $\begin{array}{c}-0,0011^{* * *} \\
(0,0001)\end{array}$ & $\begin{array}{c}-0,0029 * * * \\
(0,0002)\end{array}$ & 0,4352 & 8,7065 & 79 \\
\hline DOORS AND WINDOWS & $\begin{array}{c}0,0550 \\
(0,5796) \\
\end{array}$ & $\begin{array}{r}-0,0001 \\
(0,5475) \\
\end{array}$ & $\begin{array}{c}0,0000 \\
(0,5231) \\
\end{array}$ & $\begin{array}{r}0,0000 \\
(0,9842) \\
\end{array}$ & $\begin{array}{c}0,0798 \\
(0,2514) \\
\end{array}$ & $\begin{array}{c}-0,0005^{* *} \\
(0,0268)\end{array}$ & $\begin{array}{r}-0,0009 \\
(0,1134) \\
\end{array}$ & 0,1641 & 2,9628 & 79 \\
\hline
\end{tabular}

Table 10. Financial development controlled by economic outcomes on two different samples.

\begin{tabular}{lcccccc}
\hline & $\begin{array}{c}\text { CIVIL } \\
\text { LAW }\end{array}$ & TAX & $\begin{array}{c}\text { DOORS AND Adjusted R } \\
\text { WINDOWS }\end{array}$ & F test & Obs. \\
SantRACTS & $0,1016^{* *}$ & $0,5097^{* * *}$ & $0,5638^{* * *}$ & 0,7045 & 61,4007 & 77 \\
& $(0,0213)$ & $(0,0000)$ & $(0,0000)$ & & & \\
\hline CONTRACTS & Sample B : Wihout Départements bordering the frontier & 71 \\
& $0,1237^{* *}$ & $0,6999^{* * *}$ & $0,5159^{* * *}$ & 0,7580 & 74,0946 & \\
& $(0,0204)$ & $(0,0000)$ & $(0,0000)$ & & & \\
\hline
\end{tabular}

\section{Conclusion}

This study contributes to the debate on the causes of institutions favorable to economic development. Specifically, it provides a unique opportunity test of the very attractive but highly discussed law and finance theory. The interest of this new test is to escape the standard empirical field, which is the cross-countries comparison. We use the original historical legal division of France: the north relying on customary law close to the English common law, and the south under the Roman civil law. This dichotomy induces the same difference as the one stressed by legal origin theory between current civil law and common law countries. The theoretical mechanisms of increased rights given to the state in civil law and more flexibility to judges in customary law are valid within the Old Regime France.

To use the French legal dichotomy provides an escape from most of the difficulties faced by previous research analyzing the legal origin theory. Differences in geography, people, technology, genetics and age of institutions are very weak within France compared to international comparisons. Our sample does not suffer from potential bias due to the conditions of the transplantation of the legal system; in contrast, the two legal systems were born in the territory centuries ago. This paper also presents the first test of the legal origin theory free of any English influence, neither in terms of culture nor 
Protestantism. Finally, this analysis uses homogeneous measures through a unique fiscal and census process.

In sum, the legal origin theory is not confirmed by the analysis of Old Regime France. People living under customary law did benefit from a higher level of development but this difference can be explained by other fundamental factors. The difference in favor of the customary area is never robust when we control for one of these factors: climate, geography, policy, religion and knowledge. Unlike the theory, the civil law regime appears to be associated with higher levels of development after having controlled for a combination of other fundamental causes. Even the first prediction of legal origin theory, which is a higher level of financial development, is not verified after the control for the general level of wealth; for a similar wealth, a French person living under civil law contracts more than his counterpart living under customary law. This surprising result could be explained by several reasons that undermine the demonstration. But, at least, the main legal origin theory prediction of the negative effects of civil law is rejected for Old Regime France. This result constitutes a motivation to look for factors determining the quality of institutions other than those of legal origin.

\section{References:}

Acemoglu, D., Johnson, S. and Robinson, J. (2001). The Colonial Origins of Comparative Development: An Empirical Investigation. The American Economic Review, 91(5), pp. 1369-1401.

Acemoglu, D., Johnson, S. and Robinson, J. (2005). The Rise of Europe: Atlantic Trade, Institutional Change, and Economic Growth. American Economic Review, 95(3), pp. 546-579.

Aganin, A. and Volpin, P. (2005). History of Corporate Ownership in Italy. in Randall K. M. (ed.), A History of Corporate Governance around the World: Family Business Groups to Professional Managers, NBER Books, National Bureau of Economic Research.

Armour, J., Deakin, S., Lele, P. and Siems, M. (2009). How Do Legal Rules Evolve? Evidence from a Cross-Country Comparison of shareholder, Creditor and Worker Protection. American Journal of Comparative Law 57(3), pp. 579-629.

Ashraf, Q. and Galor, O. (2013). The 'Out of Africa' Hypothesis, Human Genetic Diversity, and Comparative Economic Development. American Economic Review, 103(1), pp. 1-46.

Association Henri Capitan (2006). Les droits de tradition civiliste en question. Paris, Société de législation comparée.

Avenel (d'), G.(1910). Découvertes d'histoire sociale 1200-1910. Paris, Flammarion.

Beck, T., Demirguc-Kunt, A. and Levine, R. (2003) Law and finance: why does legal origin matter. Journal of Comparative Economics, 31, pp. 653-675.

Becker, S. and Woessmann, L. (2009). Was Weber Wrong? A Human Capital Theory of Protestant Economic History. Quarterly Journal of Economics, 124 (2), pp. 531-596.

Bellomo M, (1995), The Common Legal Past of Euope, 1000-1800. Catholic University Press of America.

Berman, H. (2003). Law and Revolution II: The impact of the Protestant reformations on the Western legal tradition. Cambridge, MA: Belknap Press of Harvard University Press. 
Bodin, J. (1576), Les Six Livres de la République, Paris.

Bordo, M.D. and Rousseau, P.L. (2006) Legal-political factors and the historical evolution of the finance-growth link. European Review of Economic History, 10, pp. 412-444.

Bockstette, V., Areendam, C. and Putterman, L. (2002). States and Markets: The Advantage of an Early Start," Journal of Economic Growth, (7), pp. 347-69.

Chénon, (1929), Histoire générale du droit français public et privé des origines á 1815. Paris, Sirey.

Cabanel, P. (2012), Histoire des Protestants en France XVI-XXI ${ }^{\text {ème }}$. Paris, Fayard.

Comin, D., Easterly, W. and Gong, E. (2010). Was the Wealth of Nations determined in 1000 BC? American Economic Journal: Macroeconomics, 2(3), pp. 65-97.

De Dainville, F. (1968). Cartes des places protestantes en 1620, dessinées à la fin du règne de Louis XIII. Journal des savants, 4, p. 214-243.

Declareuil, J. (1925), Histoire générale du droit français, des origines à 1789. Paris, Sirey.

Delacroix, J. and Nielsen, F. (2001). The Beloved Myth: Protestantism and the Rise of Industrial Capitalism in Nineteenth-Century Europe. Social Forces, 80 (2), pp. 509-553.

Donald, B. (1973). Codification in Common Law Systems. The Austrailian Law Journal, 47, p.160.

Easterly, W. and Levine, R. (2012)0 The European Origins of Economic Development, NBER WP, n. 18162.

Fukuyama, F. (1995) Trust: The Social Virtues and the Creation of Prosperity. New York, Free Press.

Gallup, J. L., Sachs, J. D. and Mellinger, A. D. (1998). Geography and Economic Development. in Annual World Bank Conference on Development Economic, The World Bank, Washington DC.

Gennaioli, N. and Shleifer, A. (2007). The Evolution of Common Law. Journal of Political Economy, 115(1), pp0 43-68.

Giordanengo, G. (1992). Résistances intellectuelles autour de la décrétale Super Spéculant (1219). in Histoire et Société. Mélanges offerts à G. Duby. Le moine, le clerc et le prince. Vol.III, Aix-en-Provence, pp. 141-155.

Gouron, A. (1957). Les étapes de la pénétration du droit romain au Xlle siècle dans l'ancienne Septimanie. Annales du Midi, 69, pp. 103-120.

Guerriero, C. (2001). Legal Traditions and Economic Performances: Theory and Evidence. in Bouckaert, Boudewijn and Gerrit De Geest (eds.), Encyclopedia of Law and Economics, 2nd ed., Volume VII, Edward Elgar, Cheltenham, Ch. 9, 144-163.

Guiso, L., Sapienza, P. and Zingales, L. (2006). Does culture affect economic outcomes. Journal of Economic Perspectives, 20(2), pp. 23-48.

Hayek, F., 1960, The Constitution of Liberty. The University of Chicago Press, Chicago, IL.

Hermann, S. (1996). The Fate and the Future of Codification in America. American Journal of Legal History, 40(4), p. 407-437.

Hoffman, P.T., Postel-Vinay, G. and Rosenthal, J-L. (2001). Des marches sans prix, Paris, EHESS (in english, Priceless Markets: The Political Economy of Credit in Paris, 1660-1870). 
Hoffman, P.T., Postel-Vinay, G. and Rosenthal, J-L. (2004). Révolution et évolution : Les marchés de crédit notarié en France 1780-1840. Annales ESC, 59 (2), pp. 387-424.

Hoffman, P.T., Postel-Vinay, G. and Rosenthal, J-L. (2011). Entry, Information, and Financial Development: A Century of Competition between French Banks and Notaries. Working Paper, ENS.

Klerman, D. and Mahoney, P. G. (2007). Legal Origin? Journal of Comparative Economics, 35, pp. 278293.

Klimrath, H. (1843). Etudes sur les coutumes. Paris, Levraud.

Lamoreaux, N.R. and Rosenthal, J.-L. (2005) Legal regime and contractual flexibility: a comparison of business's organizational choices in France and the United States during the era of industrialization. American Law and Economics Review, 7(1), pp. 28-61.

La Porta, R., Lopez-de-Silanes, F., Shleifer, A. and Vishny, R. (1997). Legal determinants of external finance. Journal of Finance 52, pp. 1131-1150.

La Porta, R., Lopez-de-Silanes, F., Shleifer, A. and Vishny, R. (2008). The economic consequences of legal origins. Journal of Economic Literature, 46(2), pp. 285-332.

Levine, R. (2005). Law, Endowments and Property Rights. Journal of Economic Perspectives, 19(3), pp. 61-88.

Malik, A. and Temple, J.R.W. (2009). The geography of output volatility. Journal of Development Economics, 90(2), pp. 163-178.

Merryman, J.H. (1985). The Civil Law Tradition: An Introduction to the Legal Systems of Western Europe and Latin America. Stanford University Press, Stanford, CA.

Molière-Fonmaur, BL-L. (1783), Traité des Droits de Vente et Lods. Lyon, Perisse.

Musacchio, A. (2008) Can civil law countries get good institutions? Lessons from the history of creditor rights and bond markets in Brazil. Journal of Economic History, 68, pp. 80-108.

North, D. C. \& Thomas, R. P. (1973). The Rise of the Western World. A New Economic History. Cambridge University Press, Cambridge, UK.

Ogilvie, S., \& Küpker, M. and Maegraith, J. (2012). Household Debt in Early Modern Germany: Evidence from Personal Inventories. Journal of Economic History, 72(01), pp. 134-167.

Pasali, S. S. (2013). Where Is The Cheese? Synthesizing a Giant Literature on Causes and Consequences of Financial Sector Development. World Bank Working Paper, 6655.

Pissard, H. (1910). Essai sur la connaissance et la prevue des coutumes en justice dans l'ancien droit français et dans le système romano-canonique. Paris, A. Roussean.

Plucknett, T. F. T. (1939), The Relations between Roman Law and English Common Law down to the Sixteenth Century: A General Survey. The University of Toronto Law Journal, 3(1), pp. 24-50.

Plucknett, T. F. T. (1956). A Concise History of the Common Law, Fifth Edition. Union, Lawbook Exchange.

Pomeranz, K. (2000). The Great Divergence: China, Europe, and the Making of the Modern World Economy. Princeton, Princenton University Press. 
Putterman, L. and Weil, D. N. (2010). Post-1500 Population Flows and the Long-Run Determinants of Economic Growth and Inequality. Quarterly Journal of Economics, 125(4), pp. 1627-1682.

Oliver David T. (1936), Roman Law in Modern cases in English courts, Cambridge Legals Essays, Cambridge.

Postel-Vinay, G. (1998). La terre et l'argent. L'agriculture et le crédit en France du XVIIlème au début du XXème siècle. Paris, Albin Michel.

Putnam, R.D. (1993). Making Democracy Work: Civic Traditions in Modern Italy. Princeton, NJ University Press.

Rajan, R.G. and Zingales, L. (2003). The great reversals: the politics of financial development in the twentieth century. Journal of Financial Economics, 69, pp. 5-50.

Rappaport, J. and Sachs, J. D. (2003). The United States as a Coastal Nation. Journal of Economic Growth, 8(1), pp. 5-46.

Rigaudière, A., (1996). La royauté, le Parlement et le droit écrit aux alentours des années 1300. Comptes-rendus des séances de l'Académie des Inscriptions et Belles-Lettres, 140(3), pp. 885-908

Rosenthal, J-L. (2009). The Fruits of Revolution. Property Rights, Litigation and French Agriculture, 1700-1860. Cambridge, Cambridge University Press.

Rosenthal, J-L. (1993). Credit Markets and Economic Change in Southeastern France 1630-1788. Explorations in Economic History, 30(2), pp. 129-157.

Sachs, J. D., (2001). Tropical underdevelopment. National Bureau of Economic Research Working Paper 8119.

Sachs, J. D., and Warner, A. M. (1997). Sources of slow growth in African economies. Journal of African Economies, 6(3), pp. 335-76.

Sgard, J. (2006). Do legal origins matter? The case of bankruptcy laws in Europe 1808-1914. European Review of Economic History, 10, pp. 389-419.

Sokoloff, K.L. (1988). Inventive Activity in Early Industrial America: Evidence from Patent Records, 1790-1846. Journal of Economic History, 48(4), pp. 813-850.

Stulz, R.M. and Williamson, R. (2003). Culture, openness, and finance. Journal of Financial Economics, 70(3), pp. 313-349.

Xu, G. (2011). The Role of Law in Economic Growth: A Literature Review. Journal of Economic Surveys, 25(5), pp. 833-871.

Vallée, G. (1956). Compte général de la conscription de A.-A. Hargenvilliers publié d'après le manuscrit original avec une introduction et des notes. Paris, Recueil Sirey.

Watson, A. (1987). The Evolution of Law: Continued. Law and History Review, 5(2), pp. 537-570.

Weber, M. (1930). The Protestant Ethic and the Spirit of Capitalism. London, Allen and Unwin.

Weiss, G.A. (2000). The Enchantment of Codification in the Common-Law World. Yale Journal of International Law, 435, p. 454-470. 